\title{
Total factor productivity, its components and drivers
}

\author{
Franz Haider $^{1} \cdot$ Robert Kunst $^{1} \cdot$ Franz Wirl $^{1}$
}

Published online: 20 March 2020

(C) The Author(s) 2020

\begin{abstract}
We consider how the growth of total factor productivity (TFP) was affected by R\&D, trade, information and communication technology, and catching-up for the period from 1990 to 2006. Our contributions are: Firstly, to decompose TFP growth into two distinct measures for catching-up and for innovation using the Malmquist index; secondly, to update related investigations. Summarizing our findings, catching-up effects are statistically important, whereas frontier shifts tend to be smaller with increasing distance to the frontier, and large differences exist and persist between sectors and countries.
\end{abstract}

Keywords Productivity $\cdot$ Convergence $\cdot$ Malmquist index $\cdot$ R\&D $\cdot$ Trade $\cdot$ ICT

\section{Introduction}

Economic growth is one of the great miracles of human development and of rather recent origin. Productivity is considered as the "ultimate engine of growth in the global economy' (OECD 2015) and belongs to those 'two really great mysteries of economics' (Krugman 1994a, b). Historically, continuous growth is a rather recent phenomenon that has emerged only after the industrial revolution. The ongoing growth of the Chinese economy and the expansion of the Asian Tigers are recent examples of this miracle (see Lucas 1993).

Endogenous growth models (e.g., see Romer 1990) aim at explaining the Solow (1956) residual because capital accumulation cannot explain observed growth. They build on spillovers from capital, public goods, R\&D, learning by doing, etc. in order to counter the law of diminishing returns on capital. North (1989) and later Acemoglu and Robinson (2012) emphasize the role of institutions. All these theories, however, fail to explain how the industrial revolution turned economies that had been stagnant for millennia (even after the agrarian revolution 8000 BC) into

Franz Wirl

franz.wirl@univie.ac.at

1 Faculty of Business, Economics and Statistics, University of Vienna, Oskar Morgenstern Platz 1, 1090 Vienna, Austria 
forever-growing ones, and Clark (2009) offers an evolutionary explanation leading to more patience (in England). Observing Europe's industrialization in the 18th and 19th century, Gerschenkron (1962) introduced the idea of catching-up that 'economic backwardness on the eve of [a country's] industrialization' has had a persistent effect on the ensuing development. Hence, late-coming, backward countries experienced a 'sudden great spurt' of manufacturing output, high growth rates, distinctive bigger plants and enterprises, etc., or have 'a culture conducive to innovation, knowledge creation, and entrepreneurship' according to Özak (2018) for countries 'relatively more distant from the frontiers throughout the last two millennia'.

Our investigation quantifies how total factor productivity (TFP) growth is affected by factors such as R\&D, trade, and catching up based on a sample of 12 countries and 11 manufacturing industries from 1990 to 2006. Our contributions are: First, updating the widely quoted work of Griffith et al. (2004); second, introducing a different and nonparametric measure of TFP growth. Third, to decompose TFP growth into one for catching-up (moving closer to efficient frontier) and one for innovation (shifts of the efficient frontier) using the Malmquist index. Fourth, we address the role of information and communication technology (ICT) in TFP growth, which is ignored, quite surprisingly, in Griffith et al. (2004) and follow-ups. Gordon (2016) sees recent ICT advances as not comparable to the breakthroughs hundred years ago (electricity, combustion engine, telegraph, etc.). Solow's remark that 'you can see the computer age everywhere but in the productivity statistics' (cf. Jorgenson et al. 2008) has become famous as the computer productivity paradox. However, Acemoglu et al. (2014) argue the opposite: 'computers are now everywhere in our productivity statistics'.

The most important of our findings is that large differences in productivity exist across countries, industries and time. Depending on time lags, R\&D intensities affect both components; by contrast, imports have a weak positive impact on catching up but a negative one on innovation. Furthermore, an interaction of these two factors with the distance to the frontier does not add explanatory power. We find some indications that investment into information and communication technology accelerates productivity growth for an industry that occupies a larger distance from the technology frontier. In summary, catching-up effects are statistically important, frontier shifts tend to be smaller with increasing distance to the frontier, and many of our findings differ from those in Griffith et al. (2004).

After a literature review, we outline our approach, data envelopment analysis and the Malmquist index, and the data in Sect. 3 including plots of (relative) productivity in different industries and countries across time based on the data envelopment analysis. The estimation results are given in Sect. 4 and their robustness is checked in Sect. 5. An Appendix documents additional robustness checks and plots TFP at country and industry levels.

\section{Literature review}

Since research and development is a major source for innovation and technological progress, many authors focus on linking $R \& D$ and productivity. This is also a key topic on the political agenda, e.g., in the Horizon 2020 framework of the European 
Union. Coe and Helpman (1995; see also the updated version by Coe et al. 2009) add institutional variables (such as ease of doing business, patent protection and common versus statuary law) in order to empirically assess cross-country spillover effects of R\&D knowledge. The intuition is that productivity gains through R\&D do not depend exclusively on the domestic stock of knowledge but also on foreign R\&D efforts. For a sample of 22 highly developed countries, they could not only establish a positive link between domestic $\mathrm{R} \& \mathrm{D}$ efforts and productivity, but most notably a parallel link for foreign R\&D. Furthermore, trade openness increases the impact of foreign $R \& D$ spillovers and foreign $R \& D$ is more important in smaller countries.

Since Adam Smith and David Ricardo there has been a long tradition of viewing trade as beneficial. In particular, imports enable technology transfer for two reasons: First, imports enhance productivity simply by learning from others. Second, importing goods (such as machines) may itself enhance production and positively affect technological capabilities. This effect can be seen in countries suffering from sanctions on high tech goods such as Iran for decades and Russia currently. ${ }^{1}$ Considering a panel of 75 developing and industrialized countries, Connolly (2003) shows that the import of high-technology goods positively affects domestic imitation and innovation. However, Keller (1998) is skeptical about the trade-induced R\&D spillovers of Coe and Helpman (1995). Keller and Yeaple (2009) suggest that (for US manufacturing industries) technological spillovers can be attributed to foreign direct investment rather than to imports. However, Madsen (2007) finds that no less than 93\% of TFP growth was the result of international transmission of R\&D knowledge through the import channel based on estimates and simulations for 16 OECD countries over the period 1870 to 2004. Similarly, the currently contested NAFTA led to a dramatic increase in productivity and Melitz and Trefler (2012) conclude ".... Canadian manufacturing labor productivity rose by 13.8 percent [NAFTA started in 1994]. The idea that a single government policy could raise productivity by such a large amount and in such a short time-span is truly remarkable." Souare (2013) finds, also in the context of Canadian manufacturing, a robust role for international trade, FDI and R\&D in explaining TFP growth. The comprehensive study (138 countries) by Alcalá and Ciccone (2004) finds strong evidence of a causal 'effect of trade on productivity across countries'. Bloom et al. (2016) find that competition due to Chinese imports increased technical change (around 14\% of European technology upgrading 2000-7). Ding et al. (2016) present a similar result for Chinese manufacturing industries, where competition pressure from imports led to rapid technological upgrading that accelerated in firms and industries close to the world frontier.

It is somewhat surprising that the link between exports and total factor productivity (mainly studied at the firm level) is at best weak. There is an almost unanimous agreement that export is essentially a consequence of productivity growth and not the other way round. For example, in a firm-level study on Colombia, Mexico and Morocco, Clerides et al. (1998) conclude that 'the well-documented positive association between exporting and efficiency is explained by the self-selection of the more

\footnotetext{
${ }^{1}$ Hufbauer et al. (2007) find that only 34\% of economic sanctions between 1914 and 2006 were actually effective.
} 
efficient firms into the export market'. A decade earlier, Kunst and Marin (1989) find 'no (Granger) causal link from exports to productivity', for Austria. Bernard et al. (2007) document how rare, different and more efficient the exporting firms are.

The share of capital invested in ICT goods (which typically refers to computer hardware, software or telecommunication devices) has rapidly increased during the last decades, according to Nordhaus (2007) from $0.1 \%$ (in 1945) to $2.3 \%$ (in 2000) for the U.S. Investment in ICT can be seen as a form of capital deepening that can make labor more productive. Jorgenson et al. (2008) identify computer and telecommunication as the driving force 'behind the acceleration of labor productivity growth' in the U.S. from 1995 to 2000 . However, there is so far little empirical evidence of linking ICT capital to total factor productivity. Stiroh (2002) finds no significant positive impact of ICT capital on TFP growth but a strong positive impact on average labor productivity (data from 20 US manufacturing industries from 1984 to 1999). Venturini (2015) extends Coe and Helpman (1995) and finds that ICT capital, like R\&D, is 'an important source of TFP spillovers' that does not 'overlap with productivity spillovers from R\&D carried out in the underlying technological fields'. The survey of Cardona et al. (2013) finds that the majority of studies report a positive and significant impact of ICT on productivity; a similar effect is found by Lehr and Lichtenberg (1998) for federal agencies. Kuusi (2015), following a theoretical exposition, establishes a leader-follower relationship between US and EU-15 (using DEA techniques). Pieri, Vecchi and Venturini (2017) find that ICT has been effective in reducing inefficiency and in generating inter-industry spillovers (using a translog stochastic frontier). Summarizing, the recent literature offers some evidence why especially backward industries could benefit from importing ICT capital and thereby implicitly from foreign know how.

This paper follows the approach pioneered by Griffith et al. (2004) who analyzed 15 manufacturing industries over 16 years for 12 OECD countries. Using TFP levels obtained from the superlative index-number methodology of Caves et al. (1982a), the major findings are: The hypothesis of catching-up is confirmed, and high investment in R\&D leads to specifically fast catching-up. By contrast, imports did not affect the rate of TFP growth, but a larger trade share in total output seems to facilitate the process of convergence and to promote technology transfer. Human capital, measured by the percentage share of higher educated people, has positive and significant effects on productivity growth as well as on the cross-country convergence of industries.

Others have used the data set too. Notably Acemoglu et al. (2006) confirm that $R \& D$ intensities increase closer to the frontier such that $R \& D$ is more important for technology leaders. Similar approaches were applied in follow-up studies, e.g. in Cameron et al. (2005) to US and UK and 14 manufacturing industries from 1971 to 1992. They find a direct influence of R\&D on TFP, but no indication on catching-up. For imports (from the world), they are unable to establish a direct effect, only a positive interaction term. Higher education had no significant influence on TFP growth. Cameron et al. (2005) conclude that 'R\&D affects rates of UK productivity growth through innovation, while international trade facilitates the transfer of technology'.

Khan (2006) investigates the TFP gap between the United States and France for 14 manufacturing industries from 1980 to 2002. In contrast to previous studies, trade 
affects productivity directly, especially for imports from Germany, the UK and the US. The explanation is that import from technologically advanced countries might be especially important for countries that are already comparably close to the frontier. Bournakis (2012) does the same for Greek and German manufacturing industries (17 sectors, 1980-2003). While the above two-country case studies estimate a period between five and ten years to close half of the TFP gap with the USA, Bournakis reports that 'a typical Greek manufacturing industry needs about 40 years to close half the gap in technical efficiency that separates it from its German counterpart.' Bureaucracy and bad institutions may hinder technology transfer from more advanced countries.

While the two-country studies are based on around 300 observations, Mc Morrow et al. (2010) employ again a large data set (nine EU countries and the United States, 28 different industries from 1980 to 2004) with the objectives to explore the EU-US total factor productivity gap, to consider services and to focus on the importance of ICT for TFP growth. US ICT producers - as the main contributor of the EU-US gap-were benefitting more from R\&D spillovers than EU countries. Furthermore, 'industries with higher R\&D expenditures and higher adoption rates for ICT-intensive technologies appear to exhibit higher TFP growth rates'. As far as the manufacturing sector was concerned, their models show neither a significant impact of ICT capital on TFP growth nor significant interactions. Another recent and comprehensive contribution by Andrews et al. (2016) focuses on labor productivity and finds divergence rather than catching-up even after controlling for confounding factors.

\section{Empirical application}

We apply the DEA-like Malmquist index approach of Färe et al. (1994) whose TFP decomposition admits a distinction between two particular components of productivity growth: the changes of technical efficiency (catching-up) and technological progress (innovation). This differentiation may reduce some of the ambiguities from previous studies. For example, all quoted papers argue that R\&D intensities will affect rates of innovation. This conclusion is, however, not justified as such an effect may be due to catching-up in a cross-country regression. Similarly, backward entities benefit from higher import intensities either by triggering competition that improves efficiency or by importing better technology.

\subsection{Data}

The EU KLEMS Growth and Productivity Accounts 'contain industry-level measures of output, inputs and productivity for 25 European countries, Japan and the US for the period from 1970 onwards'. The well-kept KLEMS data sets have been used in other cross-country studies, e.g., in Mc Morrow et al. (2010), and in Honma and $\mathrm{Hu}$ (2014) for total factor energy efficiency. We use the Release of November 2009 (ultimately updated in March 2011) that is based on a sample of 12 countries and of all 11 manufacturing industries (see our Tables 1 and 2) such that their sum equals the KLEMS sub-category of 'Total manufacturing'. The period 1990-2006 was 
Table 1 Decision making units, countries $(i=1, \ldots, 12)$

Table 2 Sectors $(j=1, \ldots, 11)$

\begin{tabular}{lll}
\hline 1 & AUT & Austria \\
2 & BEL & Belgium \\
3 & DK & Denmark \\
4 & ESP & Spain \\
5 & FIN & Finland \\
6 & FRA & France \\
7 & GER & Germany \\
8 & ITA & Italy \\
9 & JPN & Japan \\
10 & NLD & Netherlands \\
11 & UK & United Kingdom \\
12 & USA & United States of America \\
\hline
\end{tabular}

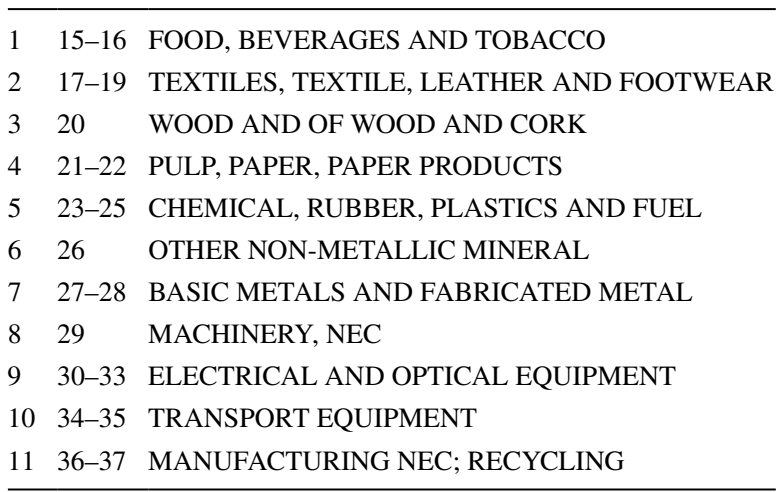

Codes refer to ISIC3

chosen, because we wanted to exclude the economic turmoil due to the financial crisis that started in 2007. Countries, industries and the variables including their data source are summarized in Tables 1,2, 3 .

\subsection{Data Envelopment Analysis}

Data Envelopment Analysis (DEA), which was introduced in Charnes et al. (1978), generates a non-parametric piecewise surface that allows assessing the levels of efficiency without the need to set weights like for conventional index numbers and without the need for price data. The productivity of a specific entity $(\theta)$ is quantified by 1 minus the distance to the frontier. Our application fulfills the criterion of 'at least three times as many observations as dimensions' (see Schiersch et al. 2015, p. 5944).

DEAs may exaggerate efficiency because not all inefficiencies are eliminated even for those at the frontier. Growiec (2012) addresses this upward bias of DEA by adding US states data to the OECD country level data. Different from stochastic 
Table 3 Variables and data sources

Labor is measured by the total hours worked by employed persons (KLEMS variable: H_EMP), and is denoted in millions of hours

Capital is capital compensation (KLEMS variable: CAP) in millions of local currency. It was converted to 1995 prices and thus deflated on the basis of the volume index (KLEMS variable: CAP_QI)

Value added (KLEMS variable: VA) is the gross value added at current basic prices in millions of local currency. It was transformed into 1995 prices by the corresponding price index (KLEMS Variable: VA_P). As in Griffith et al. (2004) and Cameron et al. (2005), local currencies are transformed to US dollars according to 'Purchasing Power Parities for GDP' of corresponding years (taken from the OECD Database: 'National Accounts: PPPs and exchange rates')

R\&D intensities established by 'STAN Indicators: R\&D intensity using value added'

Trade. Industry-level data for imports and exports - from origin or destination of the whole world-were taken from the 'STAN Database for Structural Analysis: Imports of goods at current prices'. Originally expressed in millions of local currency, trade data was normalized by gross output at current basic prices (KLEMS variable: GO)

M Imports, computed as the variable Trade above

ICT $=$ the percentage of total capital assigned to information and communication technology, was again taken from KLEMS (Variable: CAPIT)

TFPCH estimates the growth in total factor productivity based on Jorgenson and Griliches (1967) again taken from KLEMS (Variable: TFPva_I). For comparisons the according data is also downloaded (and transformed to growth rates), see Table 17 in the Appendix

TFPGAP denotes the gap relative to the efficient international competitor(s), which is based on the DEA approach explained below

TECHCH captures technological progress, i.e., shifts of the efficient frontier

EFFCH reflects movements towards the efficient frontier. Together with TECHCH, it is determined by a decomposition of TFPCH using the Malmquist index

frontier approaches, our DEA approach does require neither a priori functional specification of the technology, nor any assumptions concerning the distribution of the inefficiency terms. Compared to index number approaches, no price information (only input and output quantities) is required. A drawback of the DEA based frontier approach is its ignorance of noise and its requirement for strongly balanced panel data for the TFP estimation (the quality of EU KLEMS data mitigates this problem). Coelli et al. (2005, pp 311-314) summarizes the pros and cons and finds that DEA does best by counting the advantages of each method. Van Biesebroeck (2007) also compares the different approaches and finds that 'DEA excels when technology is heterogeneous' as is likely for a cross country comparison based on a necessarily aggregate level. Applying different methods to EU KLEMS data, Giraleas (2013) finds that 'DEA (and growth accounting) are likely to be most accurate estimates of technical inefficiency.' De Loecker and Van Biesebroeck (2016) emphasizes the role of market power, which is reduced with increased competition from imports, if evaluating (revenue based) TFP.

Figure 1 illustrates the evolution of relative TFP from 1989 until 2006 for all 12 DMUs and for total manufacturing (derived by an input-oriented, constant-returnsto-scale DEA methodology); the development of each industrial sector in each country is shown in the Appendix. Although the countries can be identified (by colors), this is not the major point of Fig. 1. Instead, the important and most striking observations are: First, the large differences in efficiencies with low efficiencies at $50 \%$ and in some sectors even as low as $20 \%$ (e.g., in basic metals); second, the average 

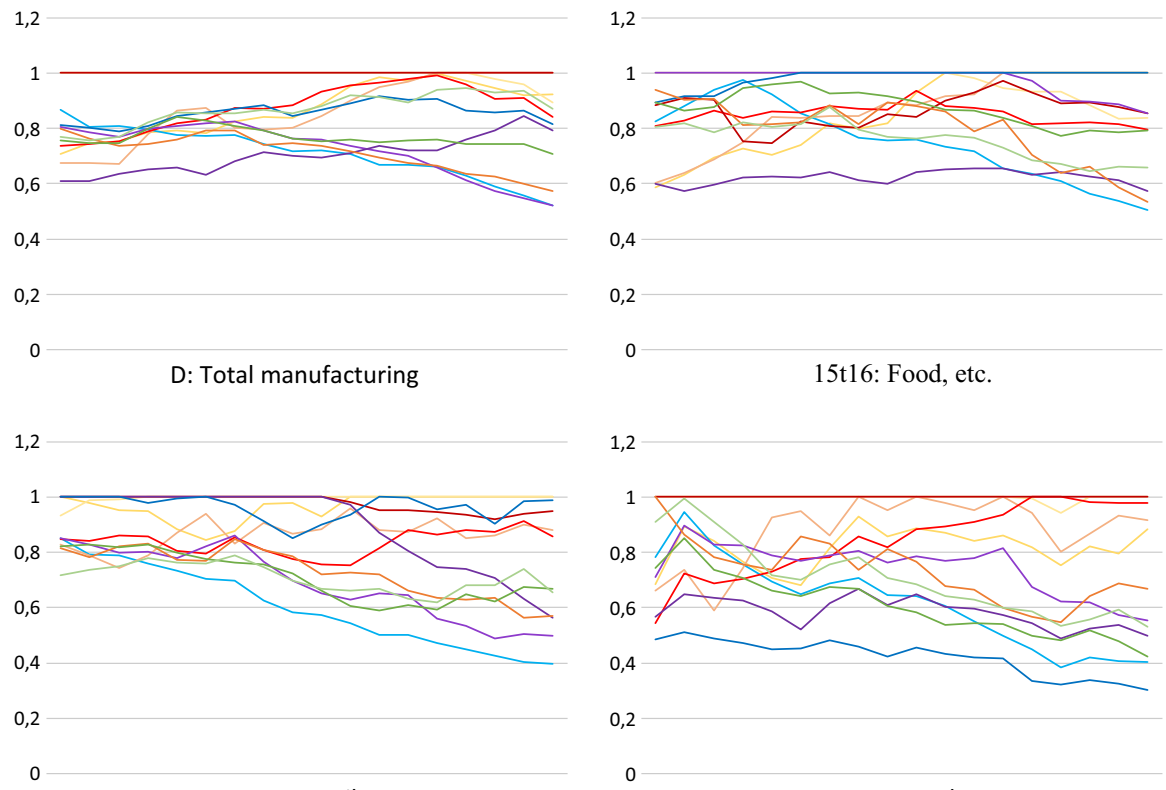

17t19: Textiles

20: Wood
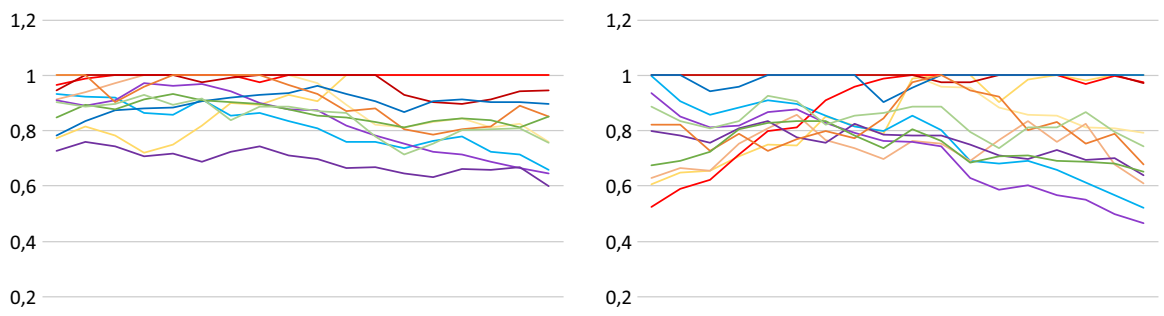

21t22: Pulp, Paper, etc.

23t25: Chemical, etc.

1,2

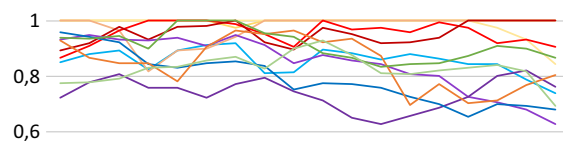

0,4

0,4

0,2

0,2

26: Non-metallic Minerals

27t28: Basic metals

Fig. 1 DEA-based TFP Levels

distance from the frontier as well as the variance of TFPs has rather increased than decreased over time. Therefore, no overall catching up is observable at this level during 1990-2006. 

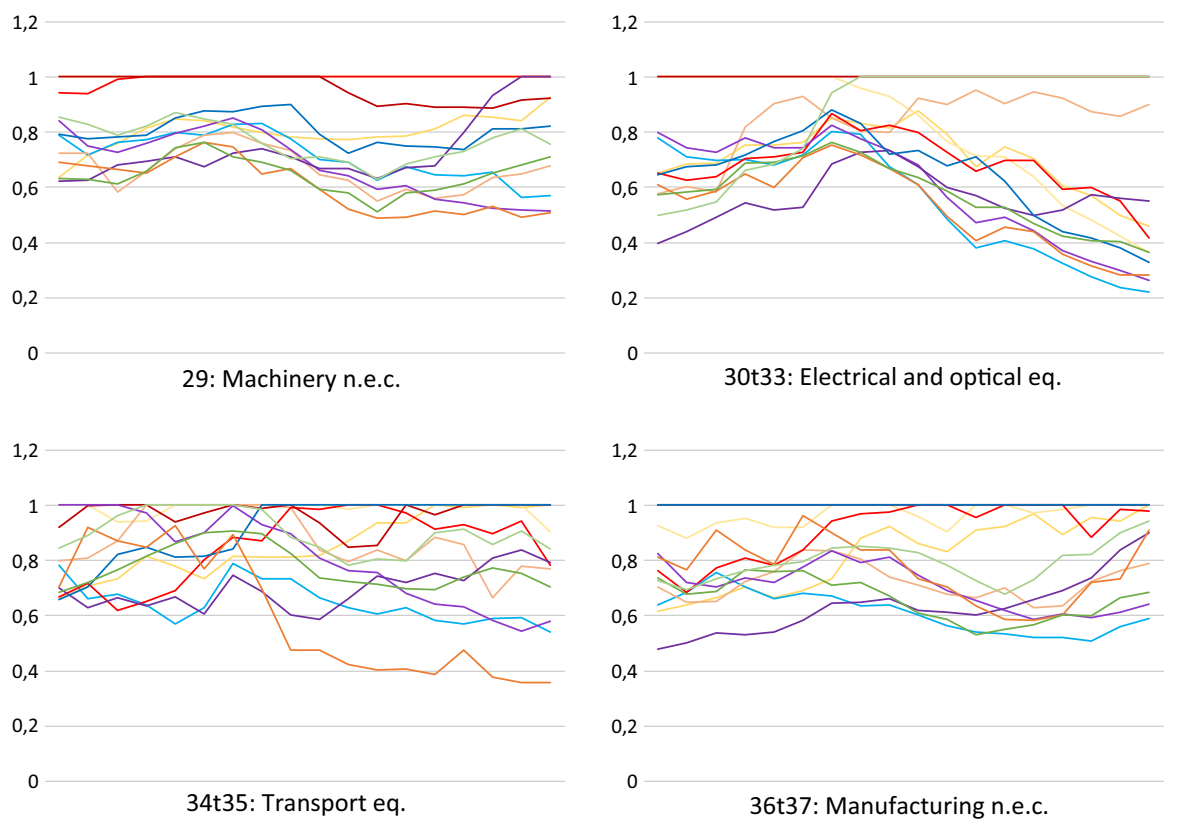

Legend

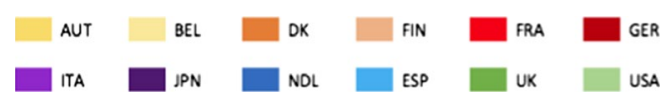

Fig. 1 (continued)

\subsection{Malmquist Index and Decomposition}

Total factor productivity shows huge fluctuations as can be seen from Fig. 1. TFP indices should reflect these changes. Caves et al. (1982b) proposed a particular TFP index and named it Malmquist index referring to Sten Malmquist (1917-2004), who had already in the 1950s applied a distance function methodology. Malmquist index approaches are characterized as distance functions that assess TFP changes between two points in time. Färe et al. (1994) propose an approach that allows decomposing TFP changes into different sub-components based on DEA. Our objective is to split total factor productivity changes into (i) a catching-up term (EFFCH) that reflects movements towards the efficient frontier, and (ii) a frontier shift (TECHCH) capturing technological progress. This accounts for the demand for a decomposition, "the ability to disentangle productivity changes into components associated with these factors may prove to be the most important application of these indexes', according to Grosskopf (2003, p. 464).

Our empirical application uses the input-oriented approach, ${ }^{2}$ see Lee and Leem (2011). Inputs are labour and capital—whereas output is value added (for details and

\footnotetext{
${ }^{2}$ Given constant returns to scale, input- and output-oriented approaches will (essentially) return the same results.
} 
definitions, see Table 3). Total factor productivity change (TFPCH) of a production unit between two periods, $t$ and $t+1$, is estimated by the Malmquist Index,

$$
\operatorname{TFPCH}_{I}^{t}=\frac{E_{I}^{t}\left(x^{t+1}, y^{t+1}\right)}{E_{I}^{t}\left(x^{t}, y^{t}\right)},
$$

where $E_{I}^{t}($.$) is the input-oriented distance function (relative to production technology$ of period $t$ ) and the subscript $I$ indicates the input orientation; $x$ is a vector of (two) inputs, and $y$ a scalar output corresponding to the periods $t$ and respectively $t+1$. Using the production technology of $t+1$ as reference, one can alternatively compute the change from:

$$
\operatorname{TFPCH}_{I}^{t+1}=\frac{E_{I}^{t+1}\left(x^{t+1}, y^{t+1}\right)}{E_{I}^{t+1}\left(x^{t}, y^{t}\right)}
$$

Since both results are not identical (except for Hicks neutrality), Caves et al. (1982b) propose the geometric mean for their definition of the Malmquist Productivity Index,

$$
\operatorname{TFPCH} H_{I}^{G}=\left[\left(\frac{\mathrm{E}_{\mathrm{I}}^{\mathrm{t}}\left(\mathrm{x}^{\mathrm{t}+1}, \mathrm{y}^{\mathrm{t}+1}\right)}{\mathrm{E}_{\mathrm{I}}^{\mathrm{t}}\left(\mathrm{x}^{\mathrm{t}}, \mathrm{y}^{\mathrm{t}}\right)}\right) \cdot\left(\frac{\mathrm{E}_{\mathrm{I}}^{\mathrm{t}}\left(\mathrm{x}^{\mathrm{t}+1}, \mathrm{y}^{\mathrm{t}+1}\right)}{\mathrm{E}_{\mathrm{I}}^{\mathrm{t}+1}\left(\mathrm{x}^{\mathrm{t}}, \mathrm{y}^{\mathrm{t}}\right)}\right)\right]^{1 / 2}
$$

A value greater than 1 indicates TFP growth between two periods: in the second period, the same quantity of input generates more output. By contrast, a decline of TFP would result in TFPCH $<1$.

Following Färe et al. (1994) allows for splitting TFPCH into two components:

$$
T F P C H_{I}^{G}=\left(\frac{E_{I}^{t+1}\left(x^{t+1}, y^{t+1}\right)}{E_{I}^{t}\left(x^{t}, y^{t}\right)}\right) \cdot\left[\left(\frac{\mathrm{E}_{\mathrm{I}}^{\mathrm{t}}\left(\mathrm{x}^{\mathrm{t}}, \mathrm{y}^{\mathrm{t}}\right)}{\mathrm{E}_{\mathrm{I}}^{\mathrm{t}+1}\left(\mathrm{x}^{\mathrm{t}}, \mathrm{y}^{\mathrm{t}}\right)}\right) \cdot\left(\frac{\mathrm{E}_{\mathrm{I}}^{\mathrm{t}}\left(\mathrm{x}^{\mathrm{t}+1}, \mathrm{y}^{\mathrm{t}+1}\right)}{\mathrm{E}_{\mathrm{I}}^{\mathrm{t}+1}\left(\mathrm{x}^{\mathrm{t}+1}, \mathrm{y}^{\mathrm{t}+1}\right)}\right)\right]^{1 / 2}
$$

Or

$$
\operatorname{TFPCH}_{I}^{G}=\mathrm{EFFCH}_{I} \cdot \mathrm{TECHCH}_{\mathrm{I}}^{\mathrm{G}}
$$

$\mathrm{EFFCH}>1$ indicates a movement closer to the frontier, and $<1$ of falling behind. Thus, EFFCH is a catching-up term that refers to productivity change through more efficient use of (existing) production technology. The remaining residual part $\mathrm{TECHCH}$ is the 'geometric mean of the shift in technology between two periods, ${ }^{3}$ and can be interpreted as innovation; again: a value greater than 1 indicates an increase, while a value less than 1 denotes a decline. Our TFP growth rates based on the Malmquist Index are highly correlated with the rates reported in KLEMS (around 0.9 and higher, see Table 17 in Appendix) which validates our approach.

Our DEA assessments are always done 'within' specific sectors and not across sectors. Different to the remark in Cooper et al. (2007) Sect. 7.5, we analyze

${ }^{3}$ Coelli et al. (2005), p. 70. 
Table 4 Selected variables-means (and standard deviations)

\begin{tabular}{|c|c|c|c|c|c|c|c|}
\hline & TFPCH & EFFCH & TECHCH & $\mathrm{R} \& \mathrm{D}$ & M & ICT & $\theta$ \\
\hline Food, beverages and tobacco (15-16) & $\begin{array}{l}0.86 \\
(4.44)\end{array}$ & $\begin{array}{l}-0.22 \\
(4.49)\end{array}$ & $\begin{array}{l}1.14 \\
(3.23)\end{array}$ & $\begin{array}{l}1.46 \\
(0.85)\end{array}$ & $\begin{array}{l}0.20 \\
(0.10)\end{array}$ & $\begin{array}{l}0.07 \\
(0.03)\end{array}$ & $\begin{array}{l}0.85 \\
(0.13)\end{array}$ \\
\hline $\begin{array}{l}\text { Textiles, Textile, Leather and footwear } \\
\text { (17-19) }\end{array}$ & $\begin{array}{l}1.19 \\
(5.24)\end{array}$ & $\begin{array}{l}-1.08 \\
(4.71)\end{array}$ & $\begin{array}{l}2.35 \\
(4.07)\end{array}$ & $\begin{array}{l}1.18 \\
(0.84)\end{array}$ & $\begin{array}{l}0.94 \\
(0.62)\end{array}$ & $\begin{array}{l}0.11 \\
(0.11)\end{array}$ & $\begin{array}{l}0.83 \\
(0.16)\end{array}$ \\
\hline Wood and of wood and cork (20) & $\begin{array}{l}1.44 \\
(6.97)\end{array}$ & $\begin{array}{l}-0.56 \\
(8.39)\end{array}$ & $\begin{array}{l}2.34 \\
(6.78)\end{array}$ & $\begin{array}{l}0.55 \\
(0.55)\end{array}$ & $\begin{array}{l}0.33 \\
(0.24)\end{array}$ & $\begin{array}{l}0.07 \\
(0.04)\end{array}$ & $\begin{array}{l}0.74 \\
(0.19)\end{array}$ \\
\hline Pulp, paper, paper products $(21-22)$ & $\begin{array}{l}0.02 \\
(4.86)\end{array}$ & $\begin{array}{l}-0.41 \\
(3.67)\end{array}$ & $\begin{array}{l}0.47 \\
(4.16)\end{array}$ & $\begin{array}{l}0.65 \\
(0.49)\end{array}$ & $\begin{array}{l}0.21 \\
(0.14)\end{array}$ & $\begin{array}{l}0.16 \\
(0.07)\end{array}$ & $\begin{array}{l}0.89 \\
(0.11)\end{array}$ \\
\hline $\begin{array}{l}\text { Chemical, rubber, plastics and fuel } \\
(23-25)\end{array}$ & $\begin{array}{l}2.37 \\
(5.52)\end{array}$ & $\begin{array}{l}-0.37 \\
(6.22)\end{array}$ & $\begin{array}{l}2.92 \\
(5.11)\end{array}$ & $\begin{array}{l}9.75 \\
(4.13)\end{array}$ & $\begin{array}{l}0.45 \\
(0.25)\end{array}$ & $\begin{array}{l}0.08 \\
(0.03)\end{array}$ & $\begin{array}{l}0.84 \\
(0.13)\end{array}$ \\
\hline Other non-metallic mineral (26) & $\begin{array}{l}1.06 \\
(5.57)\end{array}$ & $\begin{array}{l}-0.46 \\
(4.81)\end{array}$ & $\begin{array}{l}1.60 \\
(4.78)\end{array}$ & $\begin{array}{l}1.83 \\
(1.24)\end{array}$ & $\begin{array}{l}0.19 \\
(0.11)\end{array}$ & $\begin{array}{l}0.07 \\
(0.03)\end{array}$ & $\begin{array}{l}0.89 \\
(0.10)\end{array}$ \\
\hline $\begin{array}{l}\text { Basic metals and fabricated metal } \\
(27-28)\end{array}$ & $\begin{array}{l}1.81 \\
(4.89)\end{array}$ & $\begin{array}{l}0.19 \\
(5.32)\end{array}$ & $\begin{array}{l}1.73 \\
(4.43)\end{array}$ & $\begin{array}{l}1.64 \\
(0.98)\end{array}$ & $\begin{array}{l}0.32 \\
(0.18)\end{array}$ & $\begin{array}{l}0.09 \\
(0.05)\end{array}$ & $\begin{array}{l}0.79 \\
(0.13)\end{array}$ \\
\hline Machinery, nec (29) & $\begin{array}{l}1.82 \\
(6.30)\end{array}$ & $\begin{array}{l}0.00 \\
(5.71)\end{array}$ & $\begin{array}{l}1.92 \\
(5.21)\end{array}$ & $\begin{array}{l}5.63 \\
(2.13)\end{array}$ & $\begin{array}{l}0.51 \\
(0.36)\end{array}$ & $\begin{array}{l}0.14 \\
(0.07)\end{array}$ & $\begin{array}{l}0.78 \\
(0.15)\end{array}$ \\
\hline Electrical and optical equipment (30-33) & $\begin{array}{l}4.79 \\
(8.97)\end{array}$ & $\begin{array}{l}-1.82 \\
(9.17)\end{array}$ & $\begin{array}{l}7.17 \\
(8.84)\end{array}$ & $\begin{array}{l}17.60 \\
(7.78)\end{array}$ & $\begin{array}{l}0.84 \\
(0.60)\end{array}$ & - & $\begin{array}{l}0.70 \\
(0.21)\end{array}$ \\
\hline Transport equipment (34-35) & $\begin{array}{l}1.83 \\
(8.29)\end{array}$ & $\begin{array}{l}0.08 \\
(8.23)\end{array}$ & $\begin{array}{l}1.95 \\
(6.46)\end{array}$ & $\begin{array}{l}11.85 \\
(7.31)\end{array}$ & $\begin{array}{l}0.76 \\
(0.54)\end{array}$ & $\begin{array}{l}0.14 \\
(0.10)\end{array}$ & $\begin{array}{l}0.82 \\
(0.16)\end{array}$ \\
\hline Manufacturing nec; recycling (36-37) & $\begin{array}{l}1.97 \\
(6.12)\end{array}$ & $\begin{array}{l}0.94 \\
(6.29)\end{array}$ & $\begin{array}{l}1.11 \\
(4.16)\end{array}$ & $\begin{array}{l}1.46 \\
(1.36)\end{array}$ & $\begin{array}{l}0.43 \\
(0.34)\end{array}$ & $\begin{array}{l}0.11 \\
(0.04)\end{array}$ & $\begin{array}{l}0.80 \\
(0.16)\end{array}$ \\
\hline Total Manufacturing (D) & $\begin{array}{l}2.21 \\
(3.67)\end{array}$ & $\begin{array}{l}-0.08 \\
(3.49)\end{array}$ & $\begin{array}{l}2.34 \\
(3.59)\end{array}$ & $\begin{array}{l}6.24 \\
(2.30)\end{array}$ & $\begin{array}{l}0.42 \\
(0.22)\end{array}$ & $\begin{array}{l}0.11 \\
(0.03)\end{array}$ & $\begin{array}{l}0.83 \\
(0.12)\end{array}$ \\
\hline
\end{tabular}

Malmquist-based TFPCH. EFFCH and TECHCH are transformed into percentages. $\mathrm{R} \& \mathrm{D}=\mathrm{R} \& \mathrm{D}$ expenses/Value Added; $\mathrm{M}=$ Imports normalized by Gross Output; ICT=ICT/Non-ICT Capital. $\theta$ is the level of technical efficiency according to DEA (ranging from 0 to 1); ICT shares of the ICT producing sector 'Electrical and optical equipment' (30-33) are (occasionally) above 90\% and thus excluded

solely the manufacturing sector on a highly stylized and aggregated level with two inputs and one output. We follow very closely the recommended adjustments (such as adjustments for PPP) from the literature to achieve a valid comparison. And last but not least our TFP growth estimates (based on the Malmquist-type productivity Index) are confirmed by their high correlation with the TFP growth estimates published by KLEMS (and derived from a different methodology), see Table 20 in Appendix.

Table 4 summarizes the means of the key, albeit relative and sector specific, variables (including total manufacturing) and their standard deviations. This provides a first and rough overview, how much one can infer at this level and how much the following and more subtle analysis (in our case a panel regression design) modifies them. Figures 1, 2, 3, 4, 5, 6, 7, 8, 9, 10, 11, 12 and 13 highlight substantial differences and variations in efficiencies across countries and sectors although our sample consists of highly industrialized countries only. 


\section{Estimation}

We use a three-dimensional panel regression design with country, industry and time fixed effects in order to explain productivity growth rates. This follows Griffith et al. (2004) and the later follow ups. TFP measures are regressed on time-lagged explanatory variables. The Malmquist index-based TFPCH is decomposed in the components EFFCH and TECHCH, which allows for studying the impact of different independent variables on the TFP growth rate in more detail, aggregate and in its components. All three variables on the left-hand side of the regressions, namely TFPCH, EFFCH and TECHCH, are growth rates or shares and thus stationary. The main results are presented in Tables 5, 6 and 7 and complementary fittings are given in the Tables 9, 10, 11, 12, 13, 14, 15, 16 and 17 in the Appendix.

The setup of the crucial explanatory variable TFPGAP requires a modification of the standard DEA that permits multiple to be efficient. $\theta$ denotes the level of technical efficiency following Charnes et al. (1978), often abbreviated as CCR DEA model after Charnes, Cooper $\&$ Rhodes. We use $(2-\theta)$ to measure the distance to the frontier, because $1-\theta=0$ for all countries at the frontier. Of course moving from 0 to 1 changes nothing of substance in the variable TFPGAP but matters for the interactions, e.g., R\&D* TFPGAP $=\mathrm{R} \& \mathrm{D}$ instead of 0 for all countries at the frontier if using $(1-\theta)$ for the gap.

The puzzling feature of the sector electrical and optical equipment as the one with the highest TFP growth but the lowest average efficiency is due to the divergence between frontier countries and laggards as documented in the appendix; Mc Morrow et al. (2010) makes a similar observation.

The sector 'electrical and optical equipment' that produces ICT goods is an extreme outlier with its very high share of ICT capital (e.g., above $99 \%$ in the Netherlands compared with around 5\% for chemicals), and it is the sector with the highest TFP growth during our observation period $(4.8 \%$ per annum but the lowest average efficiency, $\theta=0.7$ in the last column in Table 4). Therefore, it is excluded in the regressions that include ICT on the right-hand side.

\subsection{Catching-up}

The catching-up terms, the coefficients of $\mathrm{TFGAP}_{\mathrm{t}-1}$, are all significant at the $1 \%$ level for all three endogenous variables (TFPCH, EFFCH and TECHCH). Moreover, they are robust because of similar estimated values across the different variables included on the right hand sides; this extends to the robustness tests in the Appendix (with only one exception, Table 14). Other things equal, the further a production unit is behind the frontier in period $t-1$, the bigger the rate of TFPCH at time $t$. Furthermore and even showing larger coefficients, the same relationship holds for EFFCH, indicating that backward industries will benefit specifically from catching-up. This supports the importance of catching-up and of our motivating hypothesis based on Gerschenkron (1962) and the findings in Griffith et al. (2004). However, the opposite holds for TECHCH: the further an industry is behind the frontier, the smaller is the change through technological 
progress. Laggards experience smaller frontier shifts than leaders and thus lose on the technological front. This is significant at the $1 \%$ level (except at $10 \%$ only in one case in Table 7).

\subsection{R\&D}

One- and two-year lags of the R\&D expenses are significantly increasing TFPCH at $5 \%$ and $1 \%$ levels, Table 5, columns 1 and 2 . However, the corresponding interaction terms are significantly negative. Therefore, the result in Griffith et al. (2004) of disproportionally higher return for $R \& D$ the further an industry is behind the frontier must be refuted; already Cameron et al. (2005), Khan (2006), and Bournakis (2012) failed to reproduce those findings.

For EFFCH we find (independent from their specific TFPGAP) a moderately significant positive effect of catching-up rates for one-year time lags of R\&D intensities, see Table 6 , column 1 . Industries benefit from recent R\&D expenses by moving closer to the frontier. However, due to the corresponding negative interaction terms, such a positive impact on catching-up does not have the same implications as suggested by Griffith et al. (2004, p. 883) who argued that 'the further a country lies behind the technological frontier, the greater the potential for R\&D to increase TFP growth'.

Innovation rates have a positive effect on frontier shifts (TECHCH) for twoyear lags (Table 7 , column 2, the coefficient of $R \& D_{i j t-2}$ is significant at a $5 \%$ level). The three-years lagged $R \& D$ variable has also a significant positive effect on TECHCH, but loses its significance on TFPCH (see Appendix Tables 12 and 14, column 4). Again, the interaction terms are negative and even significantly in one case (Table 7, column 5).

Our decomposition approach yields new and plausible insights into how R\&D efforts translate into productivity gains over time. While one-year lags affect the distance to the frontier (and will push the level of technical efficiency relative to the frontier), two- and three-year lags result in frontier-shifts, which capture the nature of scientific evolution, characterized by delays, perhaps more subtly than in previous studies. The findings, especially concerning TECHCH, are consistent with endogenous growth theory, which explains technological change by research and development. Nevertheless, for our sample of highly industrialized countries, interaction of high R\&D with the distance from the frontier does not lead to higher growth rates.

\subsection{Trade/import}

Griffith et al. (2004), using imports from the frontier country, and Cameron et al. (2005), using imports from the whole world, find moderately positive effects for trade and for trade-related interaction terms. Since the DEA approach may locate multiple countries at the frontier, we consider imports from the rest of the world 
(normalized by gross output). These import shares as well as the corresponding interaction terms are both insignificant for TFPCH (Table 5, and column 3).

However, at our level of decomposition, trade may have a beneficial role for catching-up. First, imports positively affect EFFCH (Table 6, column 3), statistically significant at a $10 \%$ level. This level of significance also holds in the enlarged model in column 5 (of Table 6). This suggests that importing tends to help industries by reducing their distance to the frontier. However, this positive effect of imports is countered by the negative coefficient if combined with TFPGAP.

At the level of TECHCH, higher import shares (of gross output) have a negative impact (significant at 1\%) on frontier shifts. Thus importing seems to lower domestic innovation. However, given a sufficiently large distance from the frontier, imports can trigger positive frontier shifts (TECHCH); this effect is significant at a $1 \%$ level, see Table 7, columns 3 and $5 .^{4}$ This suggests a threshold: industries close to the frontier do not benefit from imports but those at sufficient distance benefit in terms of catching up for frontier shifts (TECHCH).

Combining these observations suggests that importing is not effective for catching-up (EFFCH) in industries that are very much behind the frontier (i.e., TFPGAP is large), but beneficial for frontier shifts (TECHCH). Such a shift might result from importing up-to-date and thus expensive production technologies. Summarizing, the moderate but significant impact of imports on EFFCH (and the positive interaction term for TECHCH) supports previous findings that imports play at least some role in accelerating technology transfer. If imports are replaced by the entire trade volume of an industry-see Tables 12, 13, 14 in the Appendix-we find similar but smaller coefficients. In this case, the aforementioned impact on EFFCH becomes stronger and significant at a $1 \%$ level.

\subsection{ICT}

Similar to Mc Morrow et al. (2010, p. 173, Column 7), a one-year time lag of the ICT-capital shares shows no significant impact on TFPCH (Table 5, column 4). The same holds for interaction terms and each TFP component. Quite surprisingly, but consistent with Venturini (2015), considering longer delays, as presented in Appendix Tables 9, 10, 11, yields some indications for ICT-related spillover effects.

As mentioned, the sector electrical and optical equipment is excluded from the sample in the regressions that include ICT on the right hand side. While there is once more no indication that ICT itself is a genuine driver for total factor productivity, we find some positive effects if adding interaction terms. Four-year lagged ICT-interaction terms are strongly affecting TFPCH and EFFCH (both significant at a $1 \%$ level; Appendix Tables 9 and 10, column 4). Therefore, assuming a time lag of four years, the further a country was behind the frontier and the larger TFPGAP, the more productive are investments in ICT. Hence, laggards in terms of low relative TFP-levels may benefit from using information and communication technology at least more than the

\footnotetext{
4 The only import term that is still weakly significant is in a two-year time lag of imports for TECHCH; see Appendix Table 14.
} 
average industry. Considering three-year lags (column 3), there are again significantly positive interaction terms (at the 5\% level) on EFFCH. The long adoption processes and training requirements for realizing (relative) productivity gains may explain why the most noticeable effects appear only after a substantial delay. For example, introducing an Enterprise-Resource-Planning platform could be more beneficial in an industry where efficiency is low. The existence of ICT-induced spillovers is also supported by the positive coefficients (Appendix Tables 9 and 10; columns 1-5) for many of the ICT interaction terms (for TFPCH and $\mathrm{EFFCH}$ ).

\section{Discussion and robustness}

The decomposition approach of Färe et al. (1994) and the applied DEA methodology assume constant returns to scale. This assumption is contestable. Therefore, we ran experiments using probability weights for observations based on initial industry shares of total manufacturing from 1990 (as presented in Appendix Table 17). Such weighting procedures are perceived to be problematic although they were used in Griffith et al. (2004), Khan (2006) and Mc Morrow et al. (2010), thus the results are not further discussed. The differences are negligible anyway.

Whereas we allow for fixed industry effects, industries are not homogeneous. This limitation applies to this study as well as to its predecessors. A particular case is Electrical and optical equipment (30-33). From 1990 to 2006, this is the most dynamic manufacturing sector in terms of productivity growth (of $4.8 \%$ per year according to Table 4) and simultaneously the most R\&D intensive one. Yet at the same time it exhibits the lowest average technical efficiency $(\theta=0.7$ in the last column of Table 4), indicating that clear catching-up patterns are missing. Actually, the dominant frontier countries (US and Germany, see the charts in the Appendix) even increase their (relative) advantage with most of the other countries over time. Already Mc Morrow et al. (2010) identify this sector as the main source of the EU-US productivity gap. More evidence for the lack of a catching-up tendency of 'Electrical and optical equipment' (and special behavior of other sectors) is shown in Appendix Table 18 in which the coefficients of the TFPGAP variable are insignificant for TFPCH and EFFCH for the sector 30-33.

No matter how much non-frontier countries invest into R\&D and whether or not they benefit from knowledge spillovers, backward industries do not achieve higher growth rates than frontier countries and are therefore not able to close productivity gaps. These findings are crucial for the negative interaction terms related with R\&D. ${ }^{5}$ Possible reasons for the presence of widening productivity gaps are strong exclusiveness and concentration of knowledge or imbalances regarding human resources, which may characterize high-tech industries. After all and in spite of

\footnotetext{
5 After excluding the most dynamic sector (30t33) from panel regression models, the significant impact of R\&D only occurs for $t-2$ and TECHCH (it is therefore an essential cornerstone of the main results); after exclusion, interaction terms are insignificant, but for most models regarding TFPCH and EFFCH, they are at least positive.
} 
globalization and the view that the World is flat (C) Thomas Friedman), distinct comparative advantages of particular industries may be local, a point made by Iversen and Soskice (2019). An important observation is that gaps are increasing for certain countries (e.g., for Italy and Spain, see Appendix) simultaneously in all manufacturing industries, which runs counter to the catching-up hypothesis. However, this widening gap explains the difficulties these countries faced and still face after being hit hard by the financial crisis 2008 and the following Great Recession.

The role of R\&D as a determinant of specific TFP levels is crucial in most public debates but less clear empirically. Given that highly industrialized and knowledge driven economies like Japan show rather low TFP levels, it is to some extent questionable whether TFPGAPs adequately reflect scientific absorptive capacity, or whether they rather refer to other structural deficits. Only Griffith et al. (2004) find positive and significant interactions with R\&D.

Table 14 in the Appendix offers additional perspectives on the role of trade and, in particular, on the positive import-related interaction terms for the TECHCH model. These supplementary results suggest that the further a country is behind the frontier, the higher the share of imports. This strong relation (significant at the $1 \%$ level) suggests that imports are quantitatively more important in backward industries. However, higher lags render imports insignificant for all three variables, TFPCH, EFFCH, and TECHCH. Our explanation is that newly imported machinery can be put quickly into efficient use. The importance of imports for growth can be seen from the extreme case of how sanctions lowered economic growth recently in Iran and Russia, because import substitution leads to inefficiencies (contrary to claims of local politicians).

Although the literature finds little justification for TFP growth being driven by export activities (causality seems to run rather the other way round), we included exports (to the world) in some regressions (see Tables 12, 13 and 14). Compared to imports, results are similar because both are driven by the international economic situation and thus correlated. However, whereas exports (as well as imports) have no significant stand-alone impact on TFPCH, for the case of exports a (weakly) significant negative interaction term essentially denies a positive (general) role of exports in particular for laggards.

Our last test of robustness involves instrumental variable (IV) regressions (using higher order lags as instruments), see Tables 15, 16 and 17. This eliminates potential biases (including the Nickell bias) and confirms by and large the results in Tables 5 , 6 and 7 in terms of the estimated coefficients and their significance; in some cases, significance even increases. The coefficient of $(\text { TFPGAP } \times \text { R\&D) })_{t-1}$ becomes significant (again positive) in explaining TECHCH suggesting that R\&D might help laggards disproportionally in frontier-shifting, but this effect is fragile and it even turns negative for a two-period lag. Like for TFPCH, the interaction (TFPGAP $\times$ R\&D) $)_{-2}$ is significantly negative also for EFFCH. In particular, the coefficient of (TFPGAP $\times R \& D)_{t-2}$ is significantly negative also for $\mathrm{EFFCH}$; and there is again no 
evidence that $R \& D$ activities - specifically with respect to the distance from the frontier-would act as catalyst for catching-up. Almost all estimates of the catchup term (TFPGAP) increase and thus strengthen the importance of catching up on the growth of total factor productivity, of efficiency, and of technological progress.

\section{Conclusions}

This investigation offers insights into productivity dynamics using a panel of 12 manufacturing industries in 12 industrialized countries for 1990 to 2006. Based on a DEA and Malmquist-type Index approach, it does not only update Griffith et al. (2004) for a later period, but provides new perspectives by introducing and analyzing decomposed TFP measures.

The distance to the frontier affects TFP growth in two ways. The further an industry lies behind the frontier, the higher will be the TFP growth rates (TFPCH) and the respective component EFFCH (indicating specifically catching-up). This supports the previous findings of catching-up patterns for the extended observation period. By contrast, for TECHCH (which refers to innovation) we find the opposite relation: the bigger the TFP gaps, the smaller will be productivity growth through frontier-shifts. This suggests some asymmetry of development, which Acemoglu et al. (2017) attribute to different kinds of capitalism, and the exploration of this link could the subject of future research.

In line with endogenous growth theories, R\&D is a source of TFP growth (TFPCH). While R\&D affects EFFCH (for one year lagged R\&D intensities), it especially leads to a robust upward shift of the technology frontier (TECHCH for two year time lags of $R \& D$ expenses). However, we cannot confirm that $R \& D$ is more effective the larger the TFP gap; actually the estimated coefficients of the related interaction terms are negative. Therefore, the role of $R \& D$ in the process of catching-up is confined to EFFCH.

We find no indication for a direct impact of import shares on TFP growth. Nevertheless, the decomposed measures show evidence of a (at least minor) role for technology transfer. With respect to catching-up, imports have a moderate positive impact on EFFCH. Effects on TECHCH are ambiguous (negative for imports directly but positive if interacting with respect to the distance from the frontier). Our findings support the view that trade helps importers by accelerating technology transfer. Increasing openness to trade could therefore present a policy option for making manufacturing industries more competitive in terms of productivity-recall the observation in Melitz and Trefler (2012) for Canada benefitting from NAFTA. We also find some evidence for positive effects of ICT capital on TFP convergence. Backward industries benefit more from investments in ICT than the average industry but with a substantial delay (four-year time lag) due to the time it takes to take advantage of ICT technologies (Table 8).

Whereas one of our objectives was to update and to clarify issues open in Griffith et al. (2004) and follow ups, new questions arise. First and presumably, the most important unsolved issue is to explain the large differences in TFP levels and their 
components. Second, one would like to understand better the role of convergence. One way to address both questions is to broaden the set of explanatory variables, e.g., by including proxies for the much discussed different labor market regulations and rigidities, or for differences in management practices (see Bloom and Van Reenen (2010)), or schooling (see Vandenbussche et al. 2006). Other directions of future research are to account for the large differences between sectors that were somewhat averaged out by the use of panel regressions and for geography, i.e., the hypothesis that the spillovers depend also on distances (broadly measured but including language, culture and politics), see e.g. Aldieri and Cincera (2009).

Table 5 Results I-total factor productivity change (TFPCH)

\begin{tabular}{|c|c|c|c|c|c|}
\hline & $\begin{array}{l}(1) \\
\text { TFPCH }_{\mathrm{ij} \mathrm{t}}\end{array}$ & $\begin{array}{l}(2) \\
\text { TFPCH }_{\mathrm{ij} \mathrm{t}}\end{array}$ & $\begin{array}{l}(3) \\
\text { TFPCH }_{\mathrm{ij} \mathrm{t}}\end{array}$ & 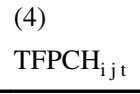 & 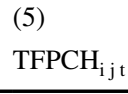 \\
\hline TFPGAP $_{\mathrm{ij} \mathrm{t}-1}$ & $\begin{array}{l}0.131^{* * * *} \\
(5.1)\end{array}$ & $\begin{array}{l}0.131 * * * \\
(4.9)\end{array}$ & $\begin{array}{l}0.114 * * * \\
(4.4)\end{array}$ & $\begin{array}{l}0.110^{* * *} \\
(4.3)\end{array}$ & $\begin{array}{l}0.145^{* * * *} \\
(5.2)\end{array}$ \\
\hline$R \& D_{i j t-1}$ & $\begin{array}{l}0.00637 * * \\
(2.4)\end{array}$ & & & & \\
\hline$R \& D_{i j t-2}$ & & $\begin{array}{l}0.00694 * * * \\
(2.8)\end{array}$ & & & $\begin{array}{l}0.00565^{* *} \\
(2.0)\end{array}$ \\
\hline$M_{i j t-1}$ & & & $\begin{array}{l}-0.0229 \\
(-0.4)\end{array}$ & & $\begin{array}{l}0.00726 \\
(0.1)\end{array}$ \\
\hline $\mathrm{ICT}_{\mathrm{ij} \mathrm{t-1}}$ & & & & $\begin{array}{l}0.0608 \\
(0.3)\end{array}$ & \\
\hline$(T F P G A P \times R \& D)_{i j t-1}$ & $\begin{array}{l}-0.00368^{* *} \\
(-2.0)\end{array}$ & & & & \\
\hline$(T F P G A P \times R \& D)_{i j ~ t-2}$ & & $\begin{array}{l}-0.00387^{* *} \\
(-2.0)\end{array}$ & & & $\begin{array}{l}-0.00239 \\
(-1.0)\end{array}$ \\
\hline$(\mathrm{TFPGAP} \times \mathrm{M})_{\mathrm{ij} \mathrm{t}-1}$ & & & $\begin{array}{l}0.000936 \\
(0.0)\end{array}$ & & $\begin{array}{l}-0.0274 \\
(-0.6)\end{array}$ \\
\hline$(\mathrm{TFPGAP} \times \mathrm{ICT})_{\mathrm{i} \mathrm{j} \mathrm{t}-1}$ & & & & $\begin{array}{l}0.0786 \\
(0.6)\end{array}$ & \\
\hline _cons & $\begin{array}{l}0.824 * * * \\
(25.4)\end{array}$ & $\begin{array}{l}0.827 * * * \\
(24.0)\end{array}$ & $\begin{array}{l}0.865^{* * * *} \\
(25.1)\end{array}$ & $\begin{array}{l}0.848 * * * \\
(24.8)\end{array}$ & $\begin{array}{l}0.818 * * * \\
(21.7)\end{array}$ \\
\hline $\begin{array}{l}\text { Country-industry fixed } \\
\text { effects and time dummies }\end{array}$ & Yes & Yes & Yes & Yes & Yes \\
\hline Obs. & 1979 & 1849 & 2244 & 2040 & 1849 \\
\hline $\mathrm{R}^{2}$ & 0.1489 & 0.1445 & 0.1477 & 0.1731 & 0.1486 \\
\hline
\end{tabular}

Dependent variable is TFPCH. Explanatory variables (time-lagged with $t-1, t-2$ ) are: TFPGAP (the distance from frontier estimated by DEA); R\&D (R\&D expenses/value added); $M$ (imports from the world/gross output); if ICT (ICT capital/Non-ICT capital) is included on the rhs, the outlier-electrical and optical equipment-is excluded from the sample. Linear panel regression with country-industry fixed effects and a full set of time-dummies for 11 manufacturing industries, 12 countries, 1990-2006; $\mathrm{R}^{2}$ within; $\mathrm{t}-* *$ statistics in parentheses use robust clustered standard errors; statistical significance: $* p<0.1$, $* * p<0.05, * * * p<0.01$ 
Table 6 Results II-efficiency change (EFFCH)

\begin{tabular}{|c|c|c|c|c|c|}
\hline & $\begin{array}{l}(1) \\
\text { EFFCH }_{\mathrm{ij} \mathrm{t}}\end{array}$ & 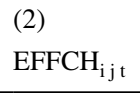 & $\begin{array}{l}(3) \\
\text { EFFCH }_{i j t}\end{array}$ & $\begin{array}{l}(4) \\
\text { EFFCH }_{\mathrm{ij} \mathrm{t}}\end{array}$ & $\begin{array}{l}(5) \\
\mathrm{EFFCH}_{\mathrm{ij}}\end{array}$ \\
\hline TFPGAP $_{\mathrm{ij} \mathrm{t-1}}$ & $\begin{array}{l}0.212^{* * * *} \\
(6.5)\end{array}$ & $\begin{array}{l}0.178^{* * * *} \\
(5.5)\end{array}$ & $\begin{array}{l}0.219^{* * *} \\
(7.3)\end{array}$ & $\begin{array}{l}0.187 * * * \\
(6.9)\end{array}$ & $\begin{array}{l}0.242^{* * *} \\
(7.2)\end{array}$ \\
\hline$R \& D_{i j t-1}$ & $\begin{array}{l}0.00660 * \\
(1.9)\end{array}$ & & & & $\begin{array}{l}0.00292 \\
(0.9)\end{array}$ \\
\hline$R \& D_{i j t-2}$ & & $\begin{array}{l}0.000698 \\
(0.2)\end{array}$ & & & \\
\hline$M_{i j t-1}$ & & & $\begin{array}{l}0.106^{*} \\
(1.9)\end{array}$ & & $\begin{array}{l}0.108^{*} \\
(1.8)\end{array}$ \\
\hline $\mathrm{ICT}_{\mathrm{ijt}-1}$ & & & & $\begin{array}{l}-0.0104 \\
(-0.1)\end{array}$ & \\
\hline$(T F P G A P \times R \& D)_{i j ~ t-1}$ & $\begin{array}{l}-0.00607 * * \\
(-2.2)\end{array}$ & & & & $\begin{array}{l}-0.00228 \\
(-0.9)\end{array}$ \\
\hline$(T F P G A P \times R \& D)_{i j ~ t-2}$ & & $\begin{array}{l}-0.00232 \\
(-0.9)\end{array}$ & & & \\
\hline$(\mathrm{TFPGAP} \times \mathrm{M})_{\mathrm{ij} \mathrm{t}-1}$ & & & $\begin{array}{l}-0.0976^{* *} \\
(-2.4)\end{array}$ & & $\begin{array}{l}-0.101 \text { ** } \\
(-2.2)\end{array}$ \\
\hline$(\mathrm{TFPGAP} \times \mathrm{ICT})_{\mathrm{i} \mathrm{j} \mathrm{t}-1}$ & & & & $\begin{array}{l}0.0329 \\
(0.2)\end{array}$ & \\
\hline _cons & $\begin{array}{l}0.756^{* * *} \\
(19.5)\end{array}$ & $\begin{array}{l}0.806^{* * * *} \\
(20.2)\end{array}$ & $\begin{array}{l}0.758 * * * \\
(19.7)\end{array}$ & $\begin{array}{l}0.793 * * * \\
(23.9)\end{array}$ & $\begin{array}{l}0.719 * * * \\
(16.4)\end{array}$ \\
\hline $\begin{array}{l}\text { Country-industry fixed } \\
\text { effects and time dummies }\end{array}$ & Yes & Yes & Yes & Yes & Yes \\
\hline Obs. & 1979 & 1849 & 2244 & 2040 & 1979 \\
\hline $\mathrm{R}^{2}$ & 0.1335 & 0.1336 & 0.1321 & 0.1255 & 0.1418 \\
\hline
\end{tabular}

Dependent variable is EFFCH, as proposed by Färe et al. (1994). All other specifications as in Table 5

Our rather surprising finding of only highly delayed effects of ICT call for more research, including a differentiation of ICT capital into particular categories, which could be feasible with the new 2016/2017 KLEMS release. The inclusion of more recent data should also allow addressing how far the Great Recession affected international differences in TFP and its drivers including catching-up. However, this extension and its focus on potential breaks due to the events in 2008 and thereafter makes sense for an analysis in a separate paper in the future. 
Table 7 Results III-technological changes (TECHCH)

\begin{tabular}{|c|c|c|c|c|c|}
\hline & (1) & (2) & (3) & (4) & (5) \\
\hline & $\mathrm{TECHCH}_{\mathrm{ijt}}$ & $\mathrm{TECHCH}_{\mathrm{ijt}}$ & $\mathrm{TECHCH}_{\mathrm{ij} \mathrm{t}}$ & $\mathrm{TECHCH}_{\mathrm{ij} \mathrm{t}}$ & $\mathrm{TECHCH}_{\mathrm{ij} \mathrm{t}}$ \\
\hline TFPGAP $_{\mathrm{ij} \mathrm{t}-1}$ & $\begin{array}{l}-0.0741 * * * \\
(-3.3)\end{array}$ & $\begin{array}{l}-0.0401 * \\
(-2.0)\end{array}$ & $\begin{array}{l}-0.0969 * * * \\
(-4.9)\end{array}$ & $\begin{array}{l}-0.0662 * * * \\
(-3.3)\end{array}$ & $\begin{array}{l}-0.0770 * * * \\
(-4.1)\end{array}$ \\
\hline$R \& D_{i j t-1}$ & $\begin{array}{l}-0.000450 \\
(-0.1)\end{array}$ & & & & \\
\hline$R \& D_{i j t-2}$ & & $\begin{array}{l}0.00599 * * \\
(2.2)\end{array}$ & & & $\begin{array}{l}0.00798 * * * \\
(3.4)\end{array}$ \\
\hline$M_{i j t-1}$ & & & $\begin{array}{l}-0.129 * * * \\
(-3.6)\end{array}$ & & $\begin{array}{l}-0.120 * * * \\
(-2.7)\end{array}$ \\
\hline $\mathrm{ICT}_{\mathrm{ij} \mathrm{t-1}}$ & & & & $\begin{array}{l}0.135 \\
(1.1)\end{array}$ & \\
\hline$(T F P G A P \times R \& D)_{i j ~ t-1}$ & $\begin{array}{l}0.00266 \\
(1.3)\end{array}$ & & & & \\
\hline$(T F P G A P \times R \& D)_{i j ~} t-2$ & & $\begin{array}{l}-0.00137 \\
(-0.9)\end{array}$ & & & $\begin{array}{l}-0.00372 * * * \\
(-2.6)\end{array}$ \\
\hline$(\text { TFPGAP } \times M)_{i j ~ t-1}$ & & & $\begin{array}{l}0.100 * * * \\
(4.8)\end{array}$ & & $\begin{array}{l}0.0937 * * * \\
(3.3)\end{array}$ \\
\hline$(\text { TFPGAP } \times \text { ICT })_{i j ~ t-1}$ & & & & $\begin{array}{l}-0.00536 \\
(-0.1)\end{array}$ & \\
\hline _cons & $\begin{array}{l}1.061^{* * * *} \\
(41.6)\end{array}$ & $\begin{array}{l}1.015^{* * * *} \\
(41.0)\end{array}$ & $\begin{array}{l}1.101 * * * \\
(42.7)\end{array}$ & $\begin{array}{l}1.044 * * * \\
(43.2)\end{array}$ & $\begin{array}{l}1.067 * * * \\
(43.0)\end{array}$ \\
\hline $\begin{array}{l}\text { Country-industry fixed } \\
\text { effects and time dum- } \\
\text { mies }\end{array}$ & Yes & Yes & Yes & Yes & Yes \\
\hline Obs. & 1979 & 1849 & 2244 & 2040 & 1849 \\
\hline $\mathrm{R}^{2}$ & 0.3213 & 0.3238 & 0.3245 & 0.3152 & 0.3301 \\
\hline
\end{tabular}

Dependent variable is TECHCH, as proposed by Färe et al. (1994). All other specifications as in Table 5

Table 8 Comparing how different factors affect TFP growth and its components

\begin{tabular}{lllll}
\hline & Griffith et al. (2004) & $\begin{array}{l}\text { TFPCH } \\
\text { This paper }\end{array}$ & EFFCH & TECHCH \\
\hline Catching up & + & + & + & - \\
R\&D & $+/+$ & $+/+$ & $+/ 0$ & $0 /+$ \\
Trade (import share, M) & 0 & 0 & + & - \\
ICT & & 0 & 0 & 0 \\
Interactions & & & & $0 / 0$ \\
R\&D & $+/+$ & $-/-$ & $-/ 0$ & + \\
Trade: imports & + & 0 & 0 & 0 \\
ICT & & 0 & & - \\
Sample period & $1974-1990$ & $1990-2006$ & & \\
\hline
\end{tabular}

\pm Indicating positive/negative significant coefficients (at least at the $10 \%$ level); 0 representing insignificance; Time lags are $(t-1)$; for R\&D intensities they are presented for both: $(t-1)$ and $(t-2)$ 
Acknowledgements Open access funding provided by University of Vienna.

Open Access This article is licensed under a Creative Commons Attribution 4.0 International License, which permits use, sharing, adaptation, distribution and reproduction in any medium or format, as long as you give appropriate credit to the original author(s) and the source, provide a link to the Creative Commons licence, and indicate if changes were made. The images or other third party material in this article are included in the article's Creative Commons licence, unless indicated otherwise in a credit line to the material. If material is not included in the article's Creative Commons licence and your intended use is not permitted by statutory regulation or exceeds the permitted use, you will need to obtain permission directly from the copyright holder. To view a copy of this licence, visit http://creativecommons.org/licen ses/by/4.0/.

\section{Appendix 1: Complementary Statistical Analyses}

See Tables 9, 10, 11, 12, 13, 14, 15, 16, 17, 18, 19, 20.

Table 9 A long-run perspective on ICT (I)

\begin{tabular}{|c|c|c|c|c|c|}
\hline & (1) & & (3) & & (5) \\
\hline & $\mathrm{TFPCH}_{\mathrm{ij} \mathrm{t}}$ & $\mathrm{TFPCH}_{\mathrm{ij} \mathrm{t}}$ & $\mathrm{TFPCH}_{\mathrm{ij} \mathrm{t}}$ & $\mathrm{TFPCH}_{\mathrm{ij} \mathrm{t}}$ & $\mathrm{TFPCH}_{\mathrm{ij} \mathrm{t}}$ \\
\hline TFPGAP $_{i j \mathrm{t}-1}$ & $\begin{array}{l}0.110^{* * *} \\
(4.3)\end{array}$ & $\begin{array}{l}0.129 * * * \\
(4.4)\end{array}$ & $\begin{array}{l}0.152^{* * * *} \\
(5.1)\end{array}$ & $\begin{array}{l}0.125^{* * * *} \\
(5.5)\end{array}$ & $\begin{array}{l}0.157 * * * \\
(5.6)\end{array}$ \\
\hline $\mathrm{ICT}_{\mathrm{ijt} t-1}$ & $\begin{array}{l}0.0608 \\
(0.3)\end{array}$ & & & & \\
\hline $\mathrm{ICT}_{\mathrm{ijt}-2}$ & & $\begin{array}{l}0.170 \\
(0.7)\end{array}$ & & & \\
\hline $\mathrm{ICT}_{\mathrm{ijt}-3}$ & & & $\begin{array}{l}-0.0523 \\
(-0.3)\end{array}$ & & \\
\hline $\mathrm{ICT}_{\mathrm{ijt}-4}$ & & & & $\begin{array}{l}-0.538^{* * *} \\
(-3.3)\end{array}$ & \\
\hline $\mathrm{ICT}_{\mathrm{ij} \mathrm{t}-5}$ & & & & & $\begin{array}{l}0.00457 \\
(0.0)\end{array}$ \\
\hline$(\text { TFPGAP } \times \text { ICT })_{i j ~ t-1}$ & $\begin{array}{l}0.0786 \\
(0.6)\end{array}$ & & & & \\
\hline$(\text { TFPGAP } \times \text { ICT })_{i ~ j ~ t-2}$ & & $\begin{array}{l}-0.0363 \\
(-0.2)\end{array}$ & & & \\
\hline$(\text { TFPGAP } \times \text { ICT })_{i j ~ t-3}$ & & & $\begin{array}{l}0.0378 \\
(0.3)\end{array}$ & & \\
\hline$(\text { TFPGAP } \times \text { ICT })_{i j ~ t-4}$ & & & & $\begin{array}{l}0.425^{* * *} \\
(3.7)\end{array}$ & \\
\hline$(\mathrm{TFPGAP} \times \mathrm{ICT})_{\mathrm{ij} \mathrm{t}-5}$ & & & & & $\begin{array}{l}0.0503 \\
(0.3)\end{array}$ \\
\hline _cons & $\begin{array}{l}0.848^{* * *} \\
(24.8)\end{array}$ & $\begin{array}{l}0.825^{* * * *} \\
(22.0)\end{array}$ & $\begin{array}{l}0.822 * * * \\
(24.5)\end{array}$ & $\begin{array}{l}0.854 * * * \\
(34.7)\end{array}$ & $\begin{array}{l}0.867 * * * \\
(28.4)\end{array}$ \\
\hline $\begin{array}{l}\text { Country-industry fixed effects } \\
\text { and time dummies }\end{array}$ & Yes & Yes & Yes & Yes & Yes \\
\hline Obs. & 2040 & 1920 & 1800 & 1680 & 1560 \\
\hline $\mathrm{R}^{2}$ & 0.1731 & 0.1633 & 0.1521 & 0.1550 & 0.1501 \\
\hline
\end{tabular}

ICT is the ratio ICT-capital/Non-ICT capital; Observations of 30-33 ('Electrical and optical equipment'; ICT producers excluded; all other specifications equal to regressions in Table 5) 
Table 10 A long-run perspective on ICT (II)

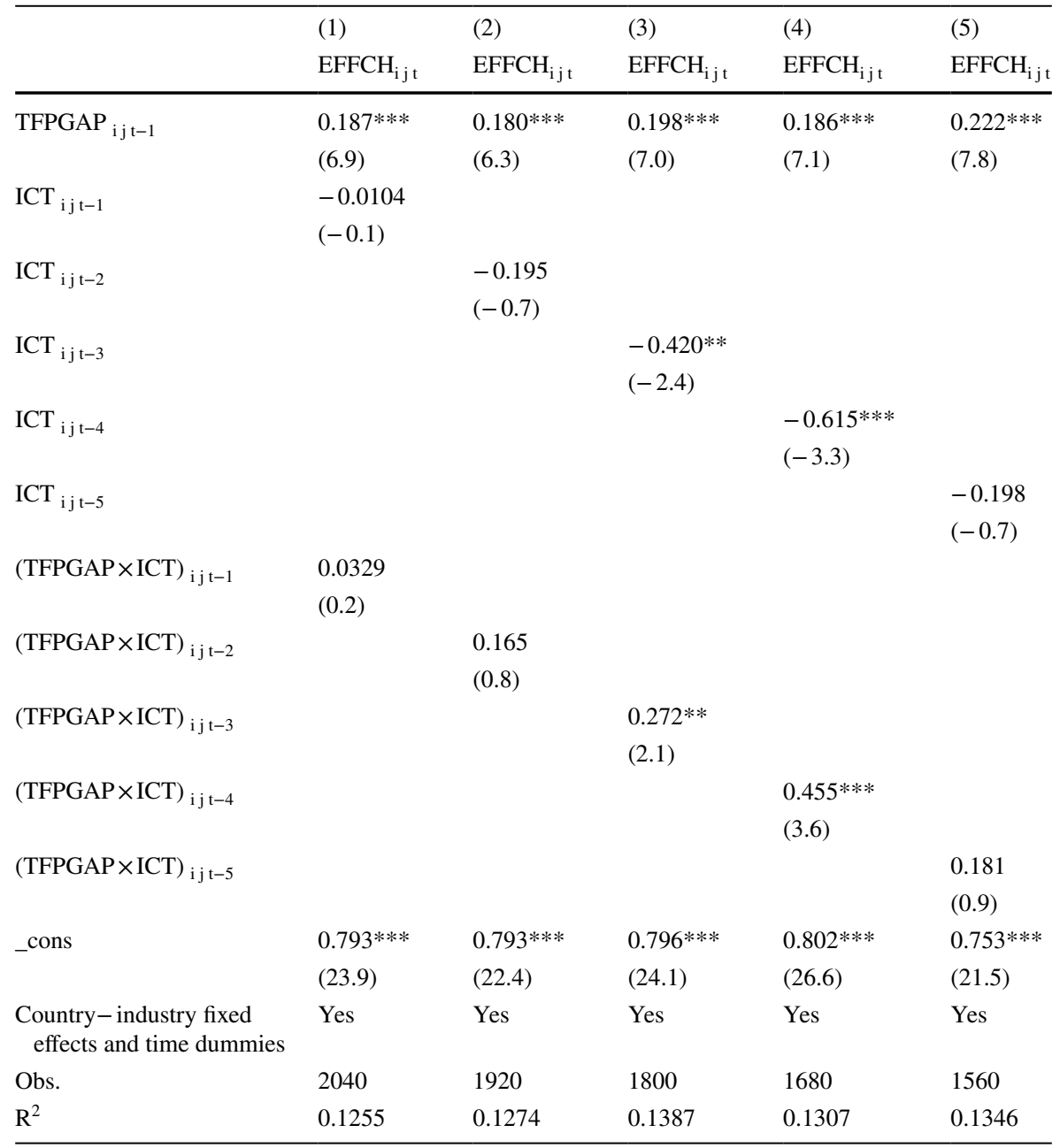


Table 11 A long-run perspective on ICT (III)

\begin{tabular}{|c|c|c|c|c|c|}
\hline & $\begin{array}{l}\text { (1) } \\
\mathrm{TECHCH}_{\mathrm{ij} \mathrm{t}}\end{array}$ & $\begin{array}{l}(2) \\
\mathrm{TECHCH}_{\mathrm{ij} \mathrm{t}}\end{array}$ & $\begin{array}{l}(3) \\
\mathrm{TECHCH}_{\mathrm{ij} \mathrm{t}}\end{array}$ & $\begin{array}{l}(4) \\
\mathrm{TECHCH}_{\mathrm{ij} \mathrm{t}}\end{array}$ & $\begin{array}{l}(5) \\
\mathrm{TECHCH}_{\mathrm{ij} \mathrm{t}}\end{array}$ \\
\hline TFPGAP $_{\mathrm{ij} \mathrm{t}-1}$ & $\begin{array}{l}-0.0662 * * * \\
(-3.3)\end{array}$ & $\begin{array}{l}-0.0466^{* * * *} \\
(-3.3)\end{array}$ & $\begin{array}{l}-0.0417 * * \\
(-2.6)\end{array}$ & $\begin{array}{l}-0.0588 * * * \\
(-3.9)\end{array}$ & $\begin{array}{l}-0.0668 * * * \\
(-4.3)\end{array}$ \\
\hline $\mathrm{ICT}_{\mathrm{ij} t-1}$ & $\begin{array}{l}0.135 \\
(1.1)\end{array}$ & & & & \\
\hline $\operatorname{ICT}_{i j t-2}$ & & $\begin{array}{l}0.385^{* * * *} \\
(3.6)\end{array}$ & & & \\
\hline $\operatorname{ICT}_{i j t-3}$ & & & $\begin{array}{l}0.412 * * * \\
(4.1)\end{array}$ & & \\
\hline $\mathrm{ICT}_{\mathrm{ij} \mathrm{t}-4}$ & & & & $\begin{array}{l}0.122 \\
(0.8)\end{array}$ & \\
\hline $\mathrm{ICT}_{\mathrm{ij} t-5}$ & & & & & $\begin{array}{l}0.233 \\
(1.4)\end{array}$ \\
\hline$(\text { TFPGAP } \times \text { ICT })_{i j ~ t-1}$ & $\begin{array}{l}-0.00536 \\
(-0.1)\end{array}$ & & & & \\
\hline$(\text { TFPGAP } \times \text { ICT })_{i j ~ t-2}$ & & $\begin{array}{l}-0.219 * * \\
(-2.5)\end{array}$ & & & \\
\hline$(\text { TFPGAP } \times \text { ICT })_{i j ~ t-3}$ & & & $\begin{array}{l}-0.272^{* * *} \\
(-3.9)\end{array}$ & & \\
\hline$(\text { TFPGAP } \times \text { ICT })_{\mathrm{i} \mathrm{j} \mathrm{t}-4}$ & & & & $\begin{array}{l}-0.0691 \\
(-0.7)\end{array}$ & \\
\hline$(\text { TFPGAP } \times \text { ICT })_{i j ~ t-5}$ & & & & & $\begin{array}{l}-0.154 \\
(-1.4)\end{array}$ \\
\hline _cons & $\begin{array}{l}1.044 * * * \\
(43.2)\end{array}$ & $\begin{array}{l}1.029 * * * \\
(55.8)\end{array}$ & $\begin{array}{l}1.022 * * * \\
(50.9)\end{array}$ & $\begin{array}{l}1.050 * * * \\
(54.3)\end{array}$ & $\begin{array}{l}1.115^{* * * *} \\
(55.7)\end{array}$ \\
\hline $\begin{array}{l}\text { Country-industry fixed } \\
\text { effects and time dum- } \\
\text { mies }\end{array}$ & Yes & Yes & Yes & Yes & Yes \\
\hline Obs. & 2040 & 1920 & 1800 & 1680 & 1560 \\
\hline $\mathrm{R}^{2}$ & 0.3152 & 0.3161 & 0.3024 & 0.2646 & 0.2332 \\
\hline
\end{tabular}


Table 12 Additional tests (I) - more lags

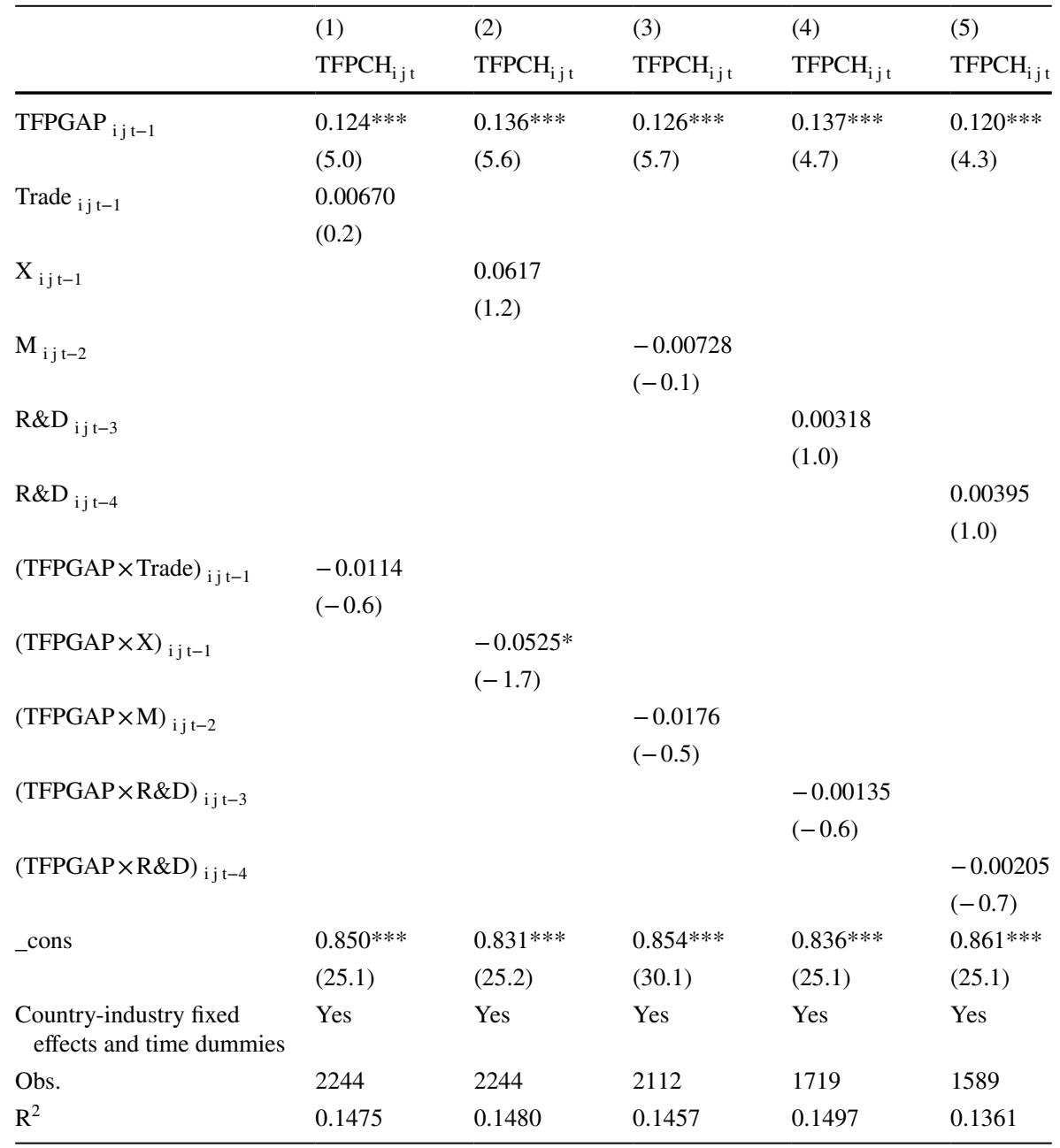

Variable Trade corresponding to imports plus exports normalized by gross output; $X$ is representing exports (to the world) normalized by gross output. All other specifications equal to regressions in Table 5 
Table 13 Additional tests (II) — more lags

\begin{tabular}{|c|c|c|c|c|c|}
\hline & $\begin{array}{l}(1) \\
\text { EFFCH }_{\mathrm{ij} \mathrm{t}}\end{array}$ & $\begin{array}{l}(2) \\
\mathrm{EFFCH}_{\mathrm{i} \mathrm{j} \mathrm{t}}\end{array}$ & $\begin{array}{l}(3) \\
\text { EFFCH }_{\mathrm{ij} \mathrm{t}}\end{array}$ & $\begin{array}{l}(4) \\
\text { EFFCH }_{\mathrm{ij} \mathrm{t}}\end{array}$ & $\begin{array}{l}(5) \\
\mathrm{EFFCH}_{\mathrm{ij} \mathrm{t}}\end{array}$ \\
\hline TFPGAP $_{\mathrm{ij} \mathrm{t}-1}$ & $\begin{array}{l}0.224 * * * \\
(7.8)\end{array}$ & $\begin{array}{l}0.222 * * * \\
(7.8)\end{array}$ & $\begin{array}{l}0.193 * * * \\
(7.2)\end{array}$ & $\begin{array}{l}0.183 * * * \\
(5.0)\end{array}$ & $\begin{array}{l}0.154 * * * \\
(4.5)\end{array}$ \\
\hline Trade $_{i j t-1}$ & $\begin{array}{l}0.0655^{* * *} \\
(2.7)\end{array}$ & & & & \\
\hline$X_{i j t-1}$ & & $\begin{array}{l}0.148^{* * * *} \\
(3.4)\end{array}$ & & & \\
\hline$M_{i j t-2}$ & & & $\begin{array}{l}0.0260 \\
(0.5)\end{array}$ & & \\
\hline$R \& D_{i j t-3}$ & & & & $\begin{array}{l}-0.00124 \\
(-0.3)\end{array}$ & \\
\hline$R \& D_{i j t-4}$ & & & & & $\begin{array}{l}0.000199 \\
(0.1)\end{array}$ \\
\hline$(\text { TFPGAP } \times \text { Trade })_{i j t-1}$ & $\begin{array}{l}-0.0590^{* * *} \\
(-3.4)\end{array}$ & & & & \\
\hline$(\text { TFPGAP } \times X)_{i j ~ t-1}$ & & $\begin{array}{l}-0.130^{* * * *} \\
(-4.3)\end{array}$ & & & \\
\hline$(\mathrm{TFPGAP} \times \mathrm{M})_{\mathrm{ij} \mathrm{t}-2}$ & & & $\begin{array}{l}-0.0531 \\
(-1.4)\end{array}$ & & \\
\hline$(T F P G A P \times R \& D)_{i j t-3}$ & & & & $\begin{array}{l}-0.000510 \\
(-0.2)\end{array}$ & \\
\hline$(T F P G A P \times R \& D)_{i j ~ t-4}$ & & & & & $\begin{array}{l}-0.000123 \\
(-0.0)\end{array}$ \\
\hline _cons & $\begin{array}{l}0.751^{* * *} \\
(20.2)\end{array}$ & $\begin{array}{l}0.751^{* * *} \\
(20.8)\end{array}$ & $\begin{array}{l}0.791 * * * \\
(22.5)\end{array}$ & $\begin{array}{l}0.823 * * * \\
(19.1)\end{array}$ & $\begin{array}{l}0.836^{* * * *} \\
(20.4)\end{array}$ \\
\hline $\begin{array}{l}\text { Country-industry fixed } \\
\text { effects and time dummies }\end{array}$ & Yes & Yes & Yes & Yes & Yes \\
\hline Obs. & 2244 & 2244 & 2112 & 1719 & 1589 \\
\hline $\mathrm{R}^{2}$ & 0.1333 & 0.1332 & 0.1319 & 0.1432 & 0.1096 \\
\hline
\end{tabular}


Table 14 Additional tests (III) — more lags

\begin{tabular}{|c|c|c|c|c|c|}
\hline & (1) & (2) & (3) & (4) & (5) \\
\hline & $\mathrm{TECHCH}_{\mathrm{ij} \mathrm{t}}$ & $\mathrm{TECHCH}_{\mathrm{ijt}}$ & $\mathrm{TECHCH}_{\mathrm{ij} \mathrm{t}}$ & $\mathrm{TECHCH}_{\mathrm{ij} \mathrm{t}}$ & $\mathrm{TECHCH}_{\mathrm{ij} \mathrm{t}}$ \\
\hline TFPGAP $_{\mathrm{ij} \mathrm{t}-1}$ & $\begin{array}{l}-0.0932 * * * \\
(-4.5)\end{array}$ & $\begin{array}{l}-0.0805^{* * * *} \\
(-3.8)\end{array}$ & $\begin{array}{l}-0.0598 * * * \\
(-3.1)\end{array}$ & $\begin{array}{l}-0.0391 * \\
(-1.9)\end{array}$ & $\begin{array}{l}-0.0292 \\
(-1.2)\end{array}$ \\
\hline Trade $_{i j t-1}$ & $\begin{array}{l}-0.0596 * * * \\
(-3.1)\end{array}$ & & & & \\
\hline$X_{i j t-1}$ & & $\begin{array}{l}-0.0897 * * \\
(-2.4)\end{array}$ & & & \\
\hline$M_{i j t-2}$ & & & $\begin{array}{l}-0.0285 \\
(-0.9)\end{array}$ & & \\
\hline$R \& D_{i j t-3}$ & & & & $\begin{array}{l}0.00420 * \\
(1.7)\end{array}$ & \\
\hline$R \& D_{i j t-4}$ & & & & & $\begin{array}{l}0.00373 \\
(1.5)\end{array}$ \\
\hline$(\text { TFPGAP } \times \text { Trade })_{i j \mathrm{t}-1}$ & $\begin{array}{l}0.0490 * * * \\
(4.4)\end{array}$ & & & & \\
\hline$(\text { TFPGAP } \times X)_{i j ~}-1$ & & $\begin{array}{l}0.0817 * * * \\
(3.6)\end{array}$ & & & \\
\hline$(\text { TFPGAP } \times M)_{i j ~}-2$ & & & $\begin{array}{l}0.0339 * \\
(1.8)\end{array}$ & & \\
\hline$(T F P G A P \times R \& D)_{i j ~} t-3$ & & & & $\begin{array}{l}-0.000783 \\
(-0.5)\end{array}$ & \\
\hline$(T F P G A P \times R \& D)_{i j ~}-4$ & & & & & $\begin{array}{l}-0.00203 \\
(-1.3)\end{array}$ \\
\hline _cons & $\begin{array}{l}1.094 * * * \\
(40.1)\end{array}$ & $\begin{array}{l}1.075^{* * * *} \\
(39.2)\end{array}$ & $\begin{array}{l}1.055^{* * * *} \\
(41.2)\end{array}$ & $\begin{array}{l}1.008 * * * \\
(38.9)\end{array}$ & $\begin{array}{l}1.021 * * * \\
(35.8)\end{array}$ \\
\hline $\begin{array}{l}\text { Country-industry fixed } \\
\text { effects and time dum- } \\
\text { mies }\end{array}$ & Yes & Yes & Yes & Yes & Yes \\
\hline Obs. & 2244 & 2244 & 2112 & 1719 & 1589 \\
\hline $\mathrm{R}^{2}$ & 0.3234 & 0.3216 & 0.3165 & 0.3043 & 0.2679 \\
\hline
\end{tabular}


Table 15 Total factor productivity change (TFPCH)_instrumental variable regression

\begin{tabular}{|c|c|c|c|c|c|}
\hline & (1) & (2) & (3) & (4) & (5) \\
\hline & $\mathrm{TFPCH}_{\mathrm{i} \mathrm{j} \mathrm{t}}$ & $\mathrm{TFPCH}_{\mathrm{ijt}}$ & $\mathrm{TFPCH}_{\mathrm{ij} \mathrm{t}}$ & $\mathrm{TFPCH}_{\mathrm{ijt}}$ & $\mathrm{TFPCH}_{\mathrm{ij} \mathrm{t}}$ \\
\hline TFPGAP $_{\mathrm{ij} \mathrm{t}-1}$ & $\begin{array}{l}0.145^{* * * *} \\
(5.0)\end{array}$ & $\begin{array}{l}0.145^{* * * *} \\
(5.3)\end{array}$ & $\begin{array}{l}0.106^{* * * *} \\
(3.9)\end{array}$ & $\begin{array}{l}0.0917 * * * \\
(3.0)\end{array}$ & $\begin{array}{l}0.155^{* * * *} \\
(4.8)\end{array}$ \\
\hline$R \& D_{i j t-1}$ & $\begin{array}{l}0.00699 * * \\
(2.5)\end{array}$ & & & & \\
\hline$R \& D_{i j t-2}$ & & $\begin{array}{l}0.00777 * * * \\
(3.0)\end{array}$ & & & $\begin{array}{l}0.00597 * * \\
(2.3)\end{array}$ \\
\hline$M_{i j t-1}$ & & & $\begin{array}{l}-0.0333 \\
(-0.8)\end{array}$ & & $\begin{array}{l}0.0164 \\
(0.3)\end{array}$ \\
\hline $\mathrm{ICT}_{\mathrm{ij} \mathrm{t-1}}$ & & & & $\begin{array}{l}-0.0882 \\
(-0.4)\end{array}$ & \\
\hline$(T F P G A P \times R \& D)_{i j ~ t-1}$ & $\begin{array}{l}-0.00418^{* *} \\
(-2.2)\end{array}$ & & & & \\
\hline$(T F P G A P \times R \& D)_{i j ~ t-2}$ & & $\begin{array}{l}-0.00450 * * \\
(-2.5)\end{array}$ & & & $\begin{array}{l}-0.00258 \\
(-1.4)\end{array}$ \\
\hline$(\text { TFPGAP } \times M)_{i j ~ t-1}$ & & & $\begin{array}{l}0.0105 \\
(0.4)\end{array}$ & & $\begin{array}{l}-0.0341 \\
(-1.0)\end{array}$ \\
\hline$(\text { TFPGAP } \times \text { ICT })_{i j ~ t-1}$ & & & & $\begin{array}{l}0.209 \\
(1.3)\end{array}$ & \\
\hline _cons & $\begin{array}{l}0.811^{* * * *} \\
(22.7)\end{array}$ & $\begin{array}{l}0.810 * * * \\
(23.9)\end{array}$ & $\begin{array}{l}0.875^{* * * *} \\
(25.3)\end{array}$ & $\begin{array}{l}0.865^{* * * *} \\
(23.5)\end{array}$ & $\begin{array}{l}0.805^{* * *} \\
(19.0)\end{array}$ \\
\hline $\begin{array}{l}\text { Country-industry fixed } \\
\text { effects and time dummies }\end{array}$ & Yes & Yes & Yes & Yes & Yes \\
\hline Obs. & 1885 & 1849 & 2112 & 1920 & 1849 \\
\hline $\mathrm{R}^{2}$ & 0.1422 & 0.1443 & 0.1428 & 0.1729 & 0.1486 \\
\hline
\end{tabular}

IV regression with fixed effects and $t$-dummies; endogenous variable is $\operatorname{TFPGAP}(t-1)$ and instrumental variable is TFPGAP $(t-2)$, other explanatory variables of each model are exogenous; dependent variable is TFPCH; $\mathrm{R}^{2}$ within; $\mathrm{t}$-statistics in parentheses, statistical significance: $* p<0.1, * * p<0.05$, *** $p<0.01$ 
Table 16 Efficiency change $(\mathrm{EFFCH})$-instrumental variable regression

\begin{tabular}{|c|c|c|c|c|c|}
\hline & $\begin{array}{l}(1) \\
\text { EFFCH }_{\mathrm{ij} \mathrm{t}}\end{array}$ & $\begin{array}{l}(2) \\
\text { EFFCH }_{\mathrm{ij} \mathrm{t}}\end{array}$ & $\begin{array}{l}(3) \\
\mathrm{EFFCH}_{\mathrm{ij} \mathrm{t}}\end{array}$ & $\begin{array}{l}(4) \\
\mathrm{EFFCH}_{\mathrm{i} \mathrm{j}}\end{array}$ & $\begin{array}{l}(5) \\
\mathrm{EFFCH}_{\mathrm{ij} \mathrm{t}} \\
\end{array}$ \\
\hline TFPGAP $_{\mathrm{ij} \mathrm{t}-1}$ & $\begin{array}{l}0.254 * * * \\
(8.5)\end{array}$ & $\begin{array}{l}0.232 * * * \\
(8.1)\end{array}$ & $\begin{array}{l}0.251 * * * \\
(9.0)\end{array}$ & $\begin{array}{l}0.198 * * * \\
(6.3)\end{array}$ & $\begin{array}{l}0.293 * * * \\
(8.6)\end{array}$ \\
\hline$R \& D_{i j t-1}$ & $\begin{array}{l}0.00854 * * * \\
(3.0)\end{array}$ & & & & $\begin{array}{l}0.00411 \\
(1.4)\end{array}$ \\
\hline$R \& D_{i j t-2}$ & & $\begin{array}{l}0.00389 \\
(1.4)\end{array}$ & & & \\
\hline$M_{i j t-1}$ & & & $\begin{array}{l}0.123^{* * * *} \\
(2.8)\end{array}$ & & $\begin{array}{l}0.141 * * * \\
(2.7)\end{array}$ \\
\hline $\mathrm{ICT}_{i \mathrm{j} \mathrm{t}-1}$ & & & & $\begin{array}{l}-0.0428 \\
(-0.2)\end{array}$ & \\
\hline$(\text { TFPGAP } \times R \& D)_{i j ~}-1$ & $\begin{array}{l}-0.00789 * * * \\
(-4.0)\end{array}$ & & & & $\begin{array}{l}-0.00330 \\
(-1.6)\end{array}$ \\
\hline$\left(\right.$ TFPGAP $\times$ R\&D) ${ }_{i j ~ t-2}$ & & $\begin{array}{l}-0.00475^{* *} \\
(-2.5)\end{array}$ & & & \\
\hline$(\text { TFPGAP } \times M)_{i j ~ t-1}$ & & & $\begin{array}{l}-0.112 * * * \\
(-3.8)\end{array}$ & & $\begin{array}{l}-0.125^{* * *} \\
(-3.4)\end{array}$ \\
\hline$(\text { TFPGAP } \times \text { ICT })_{i j ~}$-1 & & & & $\begin{array}{l}0.0655 \\
(0.4)\end{array}$ & \\
\hline _cons & $\begin{array}{l}0.711 * * * \\
(19.2)\end{array}$ & $\begin{array}{l}0.741 * * * \\
(20.9)\end{array}$ & $\begin{array}{l}0.710 * * * \\
(19.8)\end{array}$ & $\begin{array}{l}0.768 * * * \\
(20.2)\end{array}$ & $\begin{array}{l}0.660 * * * \\
(14.7)\end{array}$ \\
\hline $\begin{array}{l}\text { Country-industry fixed } \\
\text { effects and time dum- } \\
\text { mies }\end{array}$ & Yes & Yes & Yes & Yes & Yes \\
\hline Obs. & 1885 & 1849 & 2112 & 1920 & 1885 \\
\hline $\mathrm{R}^{2}$ & 0.1345 & 0.1304 & 0.1299 & 0.1276 & 0.1419 \\
\hline
\end{tabular}

IV regression; dependent variable is EFFCH - all other specifications as in Table 15 
Table 17 Technological changes (TECHCH) - instrumental variable regression

\begin{tabular}{|c|c|c|c|c|c|}
\hline & (1) & (2) & (3) & (4) & (5) \\
\hline & $\mathrm{TECHCH}_{\mathrm{ij} \mathrm{t}}$ & $\mathrm{TECHCH}_{\mathrm{ij} \mathrm{t}}$ & $\mathrm{TECHCH}_{\mathrm{ij} \mathrm{t}}$ & $\mathrm{TECHCH}_{\mathrm{ijt}}$ & $\mathrm{TECHCH}_{\mathrm{ij} \mathrm{t}}$ \\
\hline TFPGAP $_{\mathrm{ij} \mathrm{t}-1}$ & $\begin{array}{l}-0.108^{* * *} \\
(-4.7)\end{array}$ & $\begin{array}{l}-0.0832 * * * \\
(-3.8)\end{array}$ & $\begin{array}{l}-0.144 * * * \\
(-6.7)\end{array}$ & $\begin{array}{l}-0.0996^{* * * *} \\
(-4.3)\end{array}$ & $\begin{array}{l}-0.117 * * * \\
(-4.6)\end{array}$ \\
\hline$R \& D_{i j t-1}$ & $\begin{array}{l}-0.00224 \\
(-1.0)\end{array}$ & & & & \\
\hline$R \& D_{i j t-2}$ & & $\begin{array}{l}0.00344 * \\
(1.7)\end{array}$ & & & $\begin{array}{l}0.00669 * * * \\
(3.3)\end{array}$ \\
\hline$M_{i j t-1}$ & & & $\begin{array}{l}-0.165^{* * *} \\
(-4.8)\end{array}$ & & $\begin{array}{l}-0.157 * * * \\
(-3.9)\end{array}$ \\
\hline $\mathrm{ICT}_{i \mathrm{j} \mathrm{t}-1}$ & & & & $\begin{array}{l}-0.000559 \\
(-0.0)\end{array}$ & \\
\hline$(T F P G A P \times R \& D)_{i j ~ t-1}$ & $\begin{array}{l}0.00430 * * * \\
(2.8)\end{array}$ & & & & \\
\hline$(T F P G A P \times R \& D)_{i j ~ t-2}$ & & $\begin{array}{l}0.000574 \\
(0.4)\end{array}$ & & & $\begin{array}{l}-0.00296^{* *} \\
(-2.0)\end{array}$ \\
\hline$(\text { TFPGAP } \times M)_{i j ~ t-1}$ & & & $\begin{array}{l}0.129 * * * \\
(5.7)\end{array}$ & & $\begin{array}{l}0.120 * * * \\
(4.3)\end{array}$ \\
\hline$(\text { TFPGAP } \times \text { ICT })_{i j ~} t-1$ & & & & $\begin{array}{l}0.108 \\
(0.9)\end{array}$ & \\
\hline _cons & $\begin{array}{l}1.100 * * * \\
(38.6)\end{array}$ & $\begin{array}{l}1.067 * * * \\
(39.5)\end{array}$ & $\begin{array}{l}1.164 * * * \\
(42.4)\end{array}$ & $\begin{array}{l}1.090 * * * \\
(39.1)\end{array}$ & $\begin{array}{l}1.118 * * * \\
(33.2)\end{array}$ \\
\hline $\begin{array}{l}\text { Country-industry fixed } \\
\text { effects and time dum- } \\
\text { mies }\end{array}$ & Yes & Yes & Yes & Yes & Yes \\
\hline Obs. & 1885 & 1849 & 2112 & 1920 & 1849 \\
\hline $\mathrm{R}^{2}$ & 0.3174 & 0.3212 & 0.3216 & 0.3182 & 0.3283 \\
\hline
\end{tabular}

IV regression; dependent variable is TECHCH-all other specifications as in Table 15

Table 18 Industry heterogeneity (in terms of Catching-Up)

\begin{tabular}{llll}
\hline & TFPCH & EFFCH & TECHCH \\
\hline Food, beverages and tobacco (15-16) & $0.0588^{* *}$ & $0.0957^{* *}$ & -0.0328 \\
Textiles, textile, leather and footwear (17-19) & $0.1353^{* *}$ & 0.0754 & 0.0572 \\
Wood and of wood and cork (20) & $0.2176^{* *}$ & $0.2635^{* * *}$ & -0.0166 \\
Pulp, paper, paper products (21-22) & 0.0929 & $0.1291^{* *}$ & -0.0314 \\
Chemical, rubber, plastics and fuel (23-25) & $0.1273^{*}$ & $0.1853^{* * *}$ & $-0.0524 * * *$ \\
Other non-metallic mineral (26) & $0.2261^{* *}$ & $0.2797^{* * *}$ & $-0.0520^{*}$ \\
Basic metals and fabricated metal (27-28) & $0.2154^{* * *}$ & $0.2013^{* * *}$ & 0.0157 \\
Machinery, nec (29) & 0.1051 & 0.1602 & $-0.0510^{* *}$ \\
Electrical and optical equipment (30-33) & 0.0006 & 0.0473 & $-0.0232^{*}$ \\
Transport equipment (34-35) & $0.1789^{* * *}$ & $0.1816^{* * *}$ & -0.0037 \\
Manufacturing nec; recycling (36-37) & $0.2200^{* * *}$ & $0.2156^{* * *}$ & 0.0065 \\
All observations & $0.1074 * * *$ & $0.1516^{* * *}$ & $-0.0355^{*}$ \\
\hline
\end{tabular}


Table 19 R\&D, M \& ICT regressed on TFPGAP

\begin{tabular}{llll}
\hline & ${\mathrm{R} \& \mathrm{D}_{\mathrm{ij} \mathrm{t}}}$ & $\mathrm{M}_{\mathrm{ijt}}$ & $\mathrm{ICT}_{\mathrm{ij} \mathrm{t}}$ \\
\hline TFPGAP $_{\mathrm{ij} \mathrm{t-1}}$ & -0.168 & $0.355^{* * *}$ & $0.0732^{*}$ \\
& $(-0.1)$ & $(2.6)$ & $(1.8)$ \\
_cons & $4.704^{* * *}$ & -0.0265 & 0.0131 \\
& $(2.9)$ & $(-0.2)$ & $(0.3)$ \\
Country-industry fixed & Yes & Yes & Yes \\
effects and time dummies & & & \\
Obs. & 2015 & 2244 & 2244 \\
$\mathrm{R}^{2}$ & 0.0734 & 0.2619 & 0.0698 \\
\hline
\end{tabular}

Table 20 Industry-shares and TFPCH/KLEMS correlations

\begin{tabular}{lrll}
\hline Share_90 & Share_06 & $\rho$ & \\
\hline 12.84 & 10.57 & 0.912 & Food, beverages and tobacco (15-16) \\
6.44 & 3.17 & 0.884 & Textiles, textile, leather and footwear (17-19) \\
2.54 & 2.07 & 0.937 & Wood and of wood and cork (20) \\
11.24 & 8.97 & 0.901 & Pulp, paper, paper products (21-22) \\
14.94 & 17.07 & 0.912 & Chemical, rubber, plastics and fuel (23-25) \\
4.84 & 4.07 & 0.875 & Other non-metallic mineral (26) \\
13.74 & 12.57 & 0.915 & Basic metals and fabricated metal (27-28) \\
10.44 & 9.77 & 0.940 & Machinery, nec (29) \\
10.14 & 19.57 & 0.836 & Electrical and optical equipment (30-33) \\
8.34 & 8.67 & 0.904 & Transport equipment (34-35) \\
4.54 & 3.47 & 0.931 & Manufacturing nec; recycling (36-37) \\
100 & 100 & 0.875 & All observations \\
\hline
\end{tabular}

Columns 1 and 2 reflect the average industry size as share of total manufacturing for 1990 and 2006; $\rho$ is the correlation coefficient of the internal KLEMS TFP growth estimate derived from TFPva_I and TFPCH as derived by Malmquist Index 


\section{Appendix 2: Estimated TFP-Levels; 1989-2006 6}

See Figs. 2, 3, 4, 5, 6, 7, 8, 9, 10, 11, 12 and 13

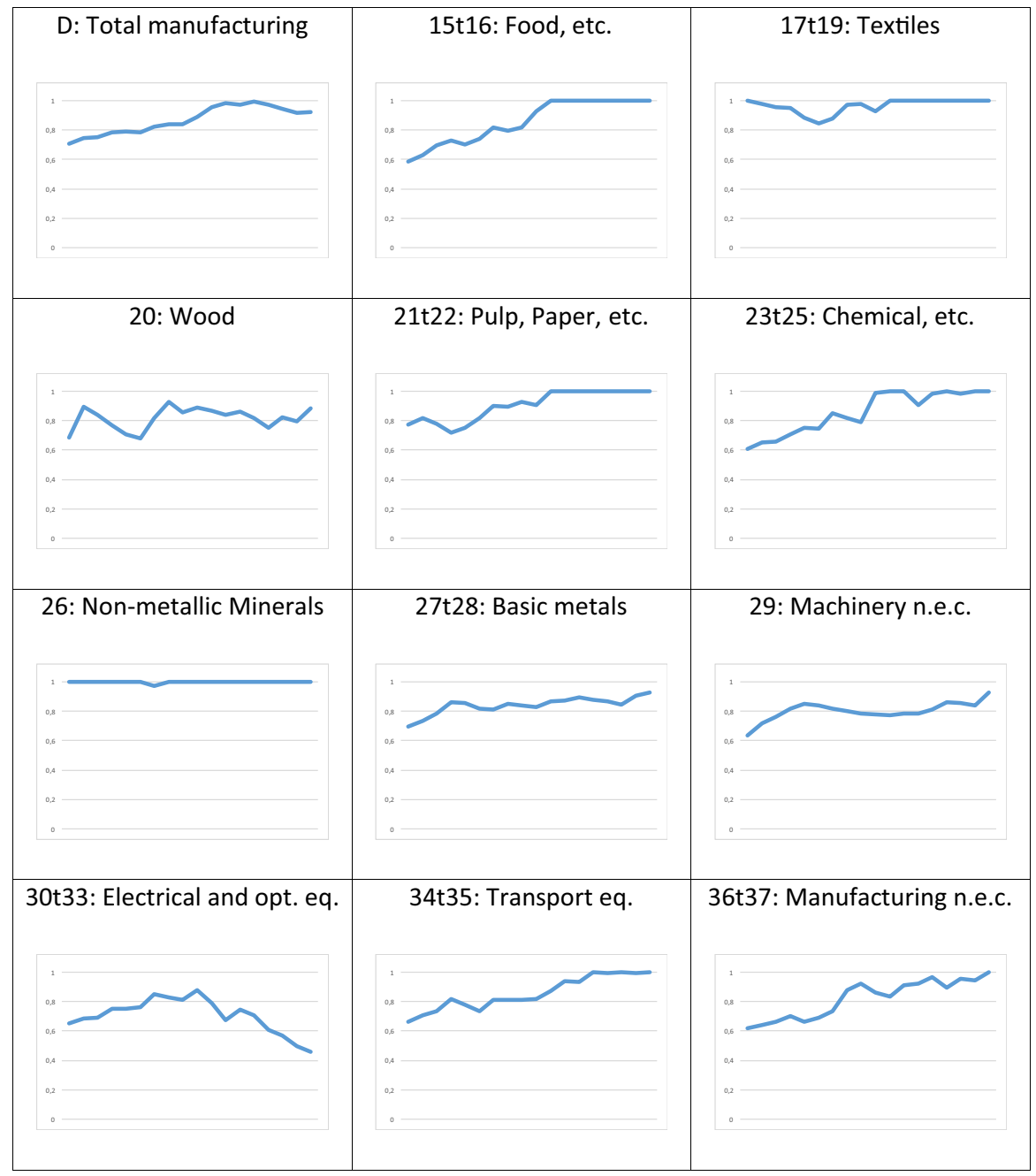

Fig. 2 Austria

\footnotetext{
${ }^{6}$ Derived by CCR DEA. $1=$ indicates the frontier.
} 


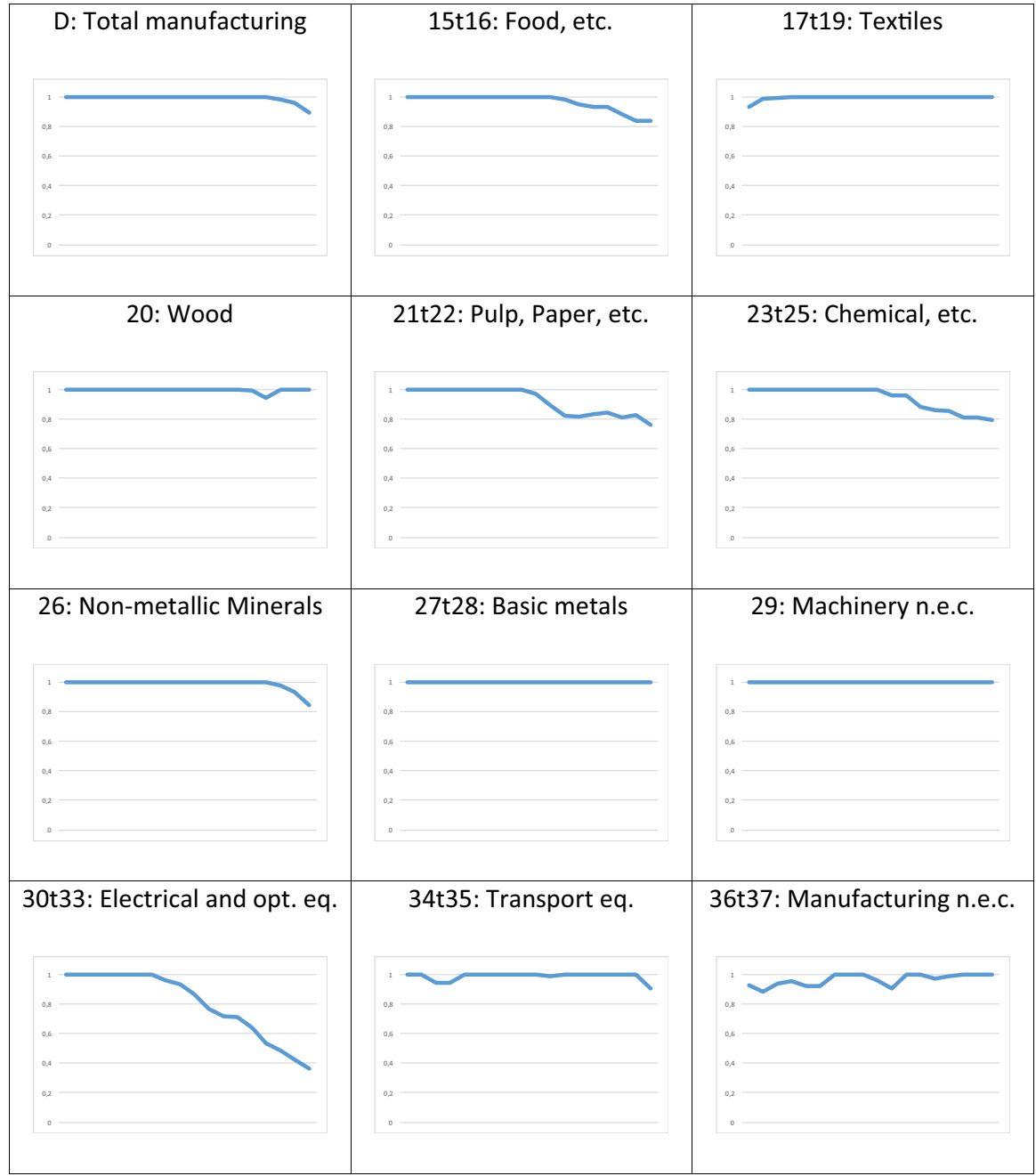

Fig. 3 Belgium 


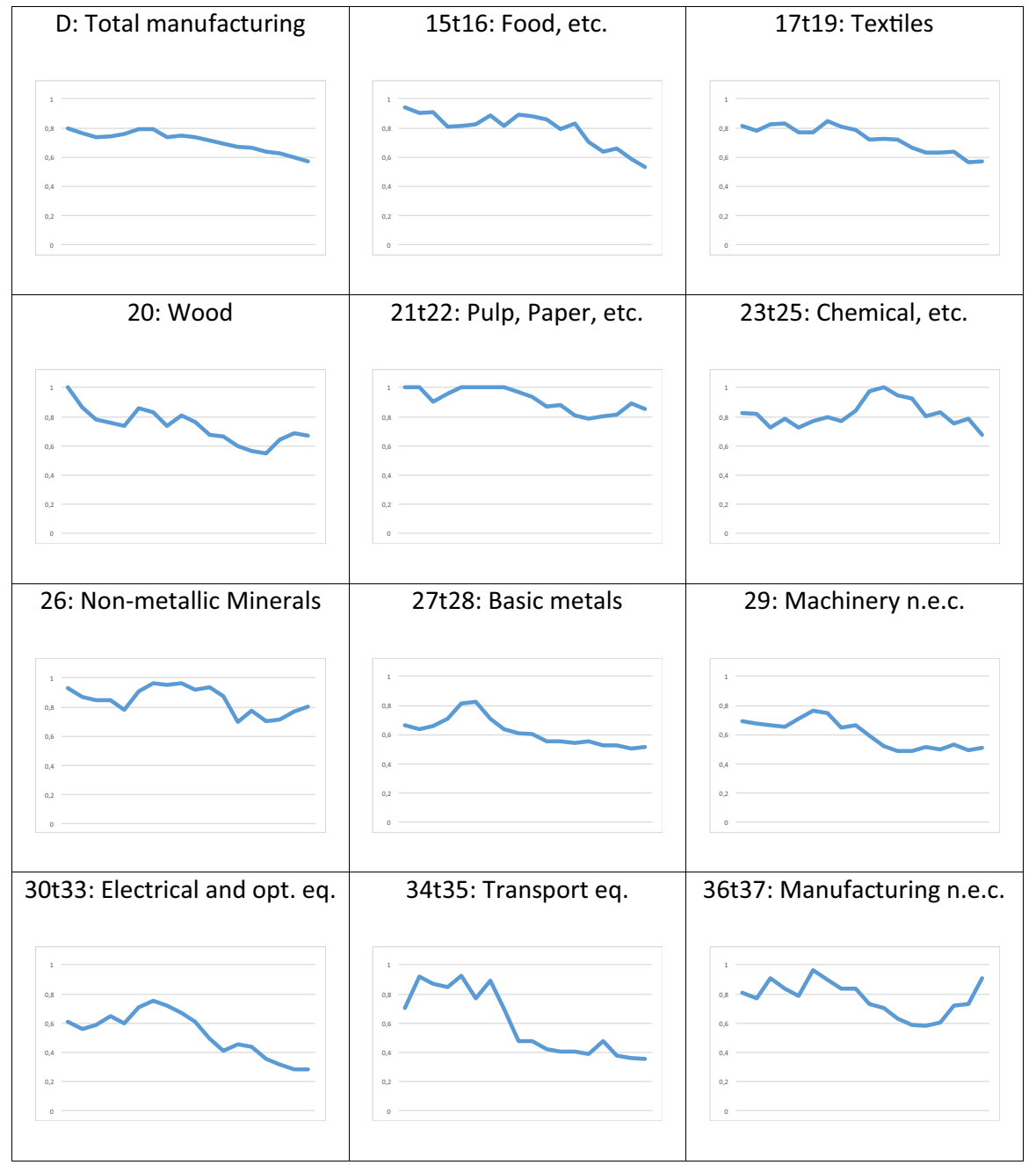

Fig. 4 Denmark 


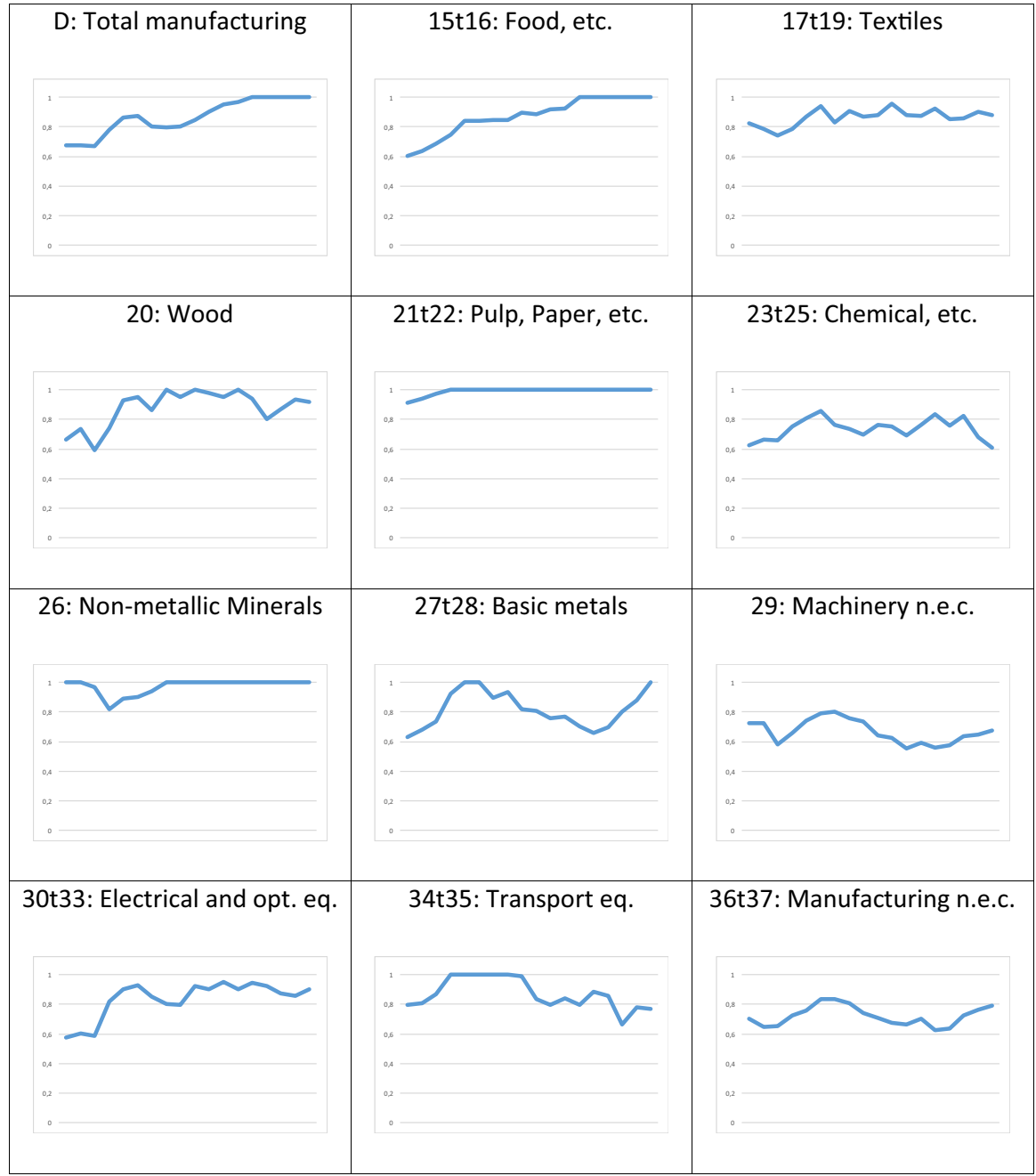

Fig. 5 Finland 


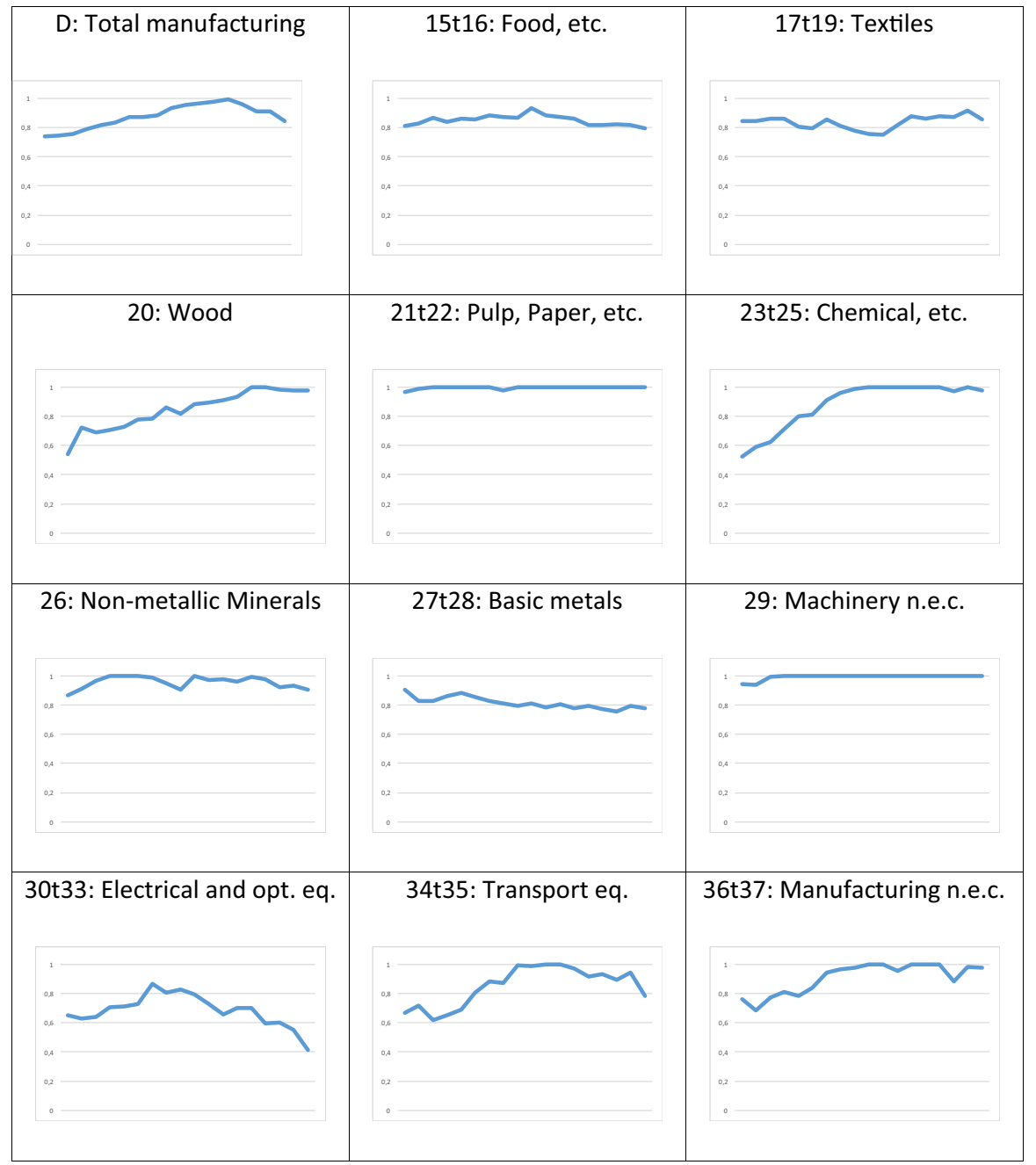

Fig. 6 France 


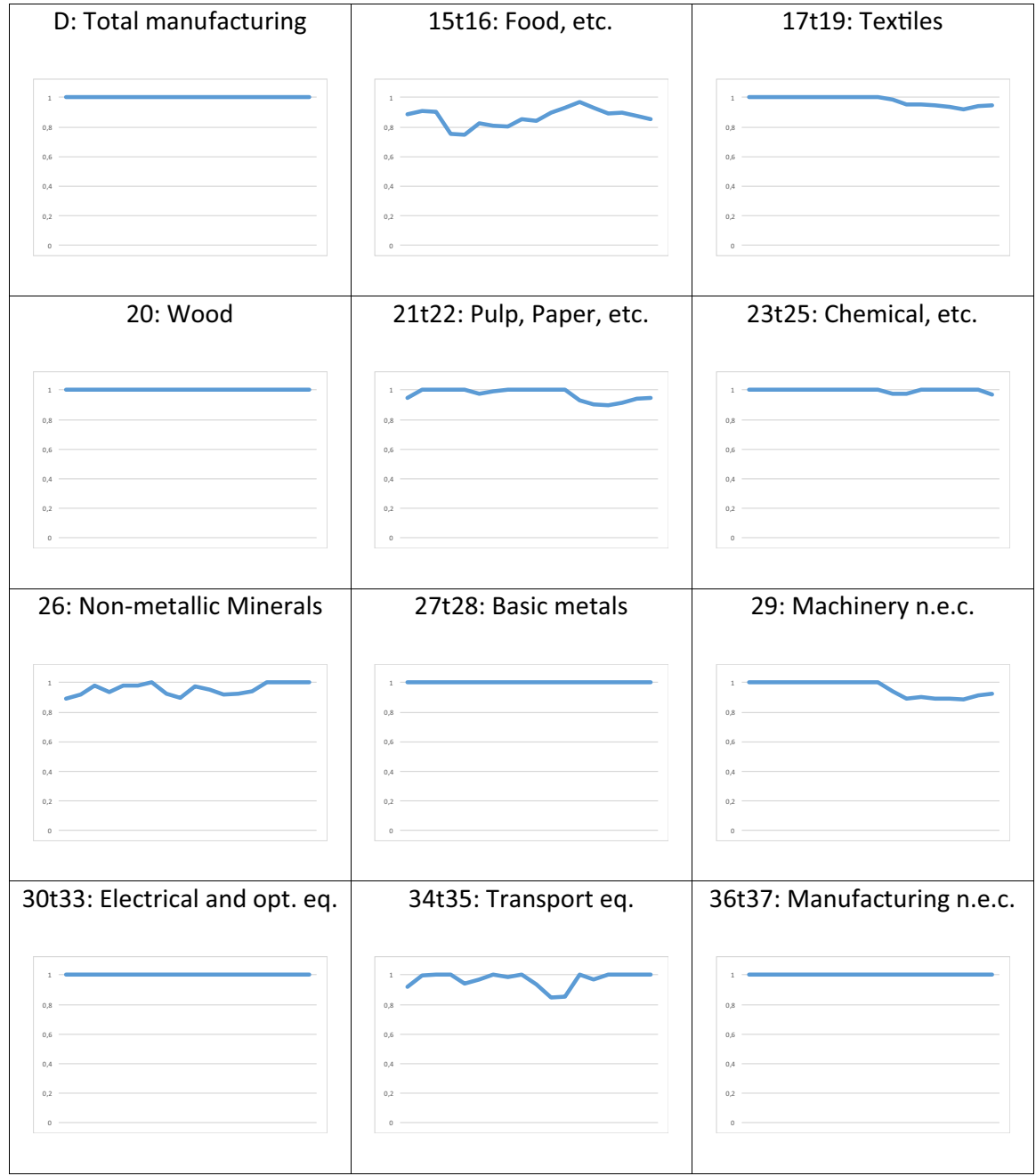

Fig. 7 Germany 


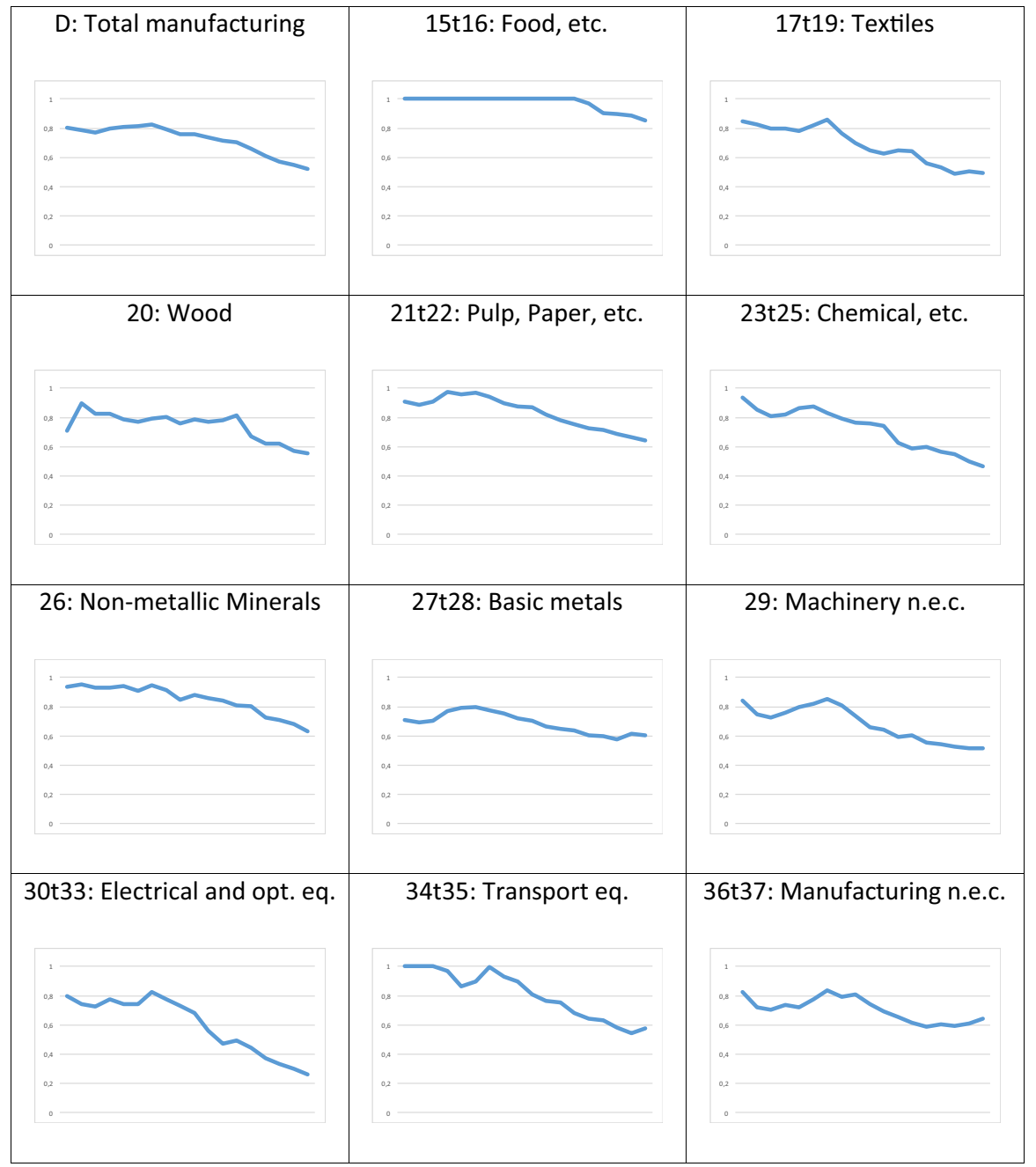

Fig. 8 Italy 


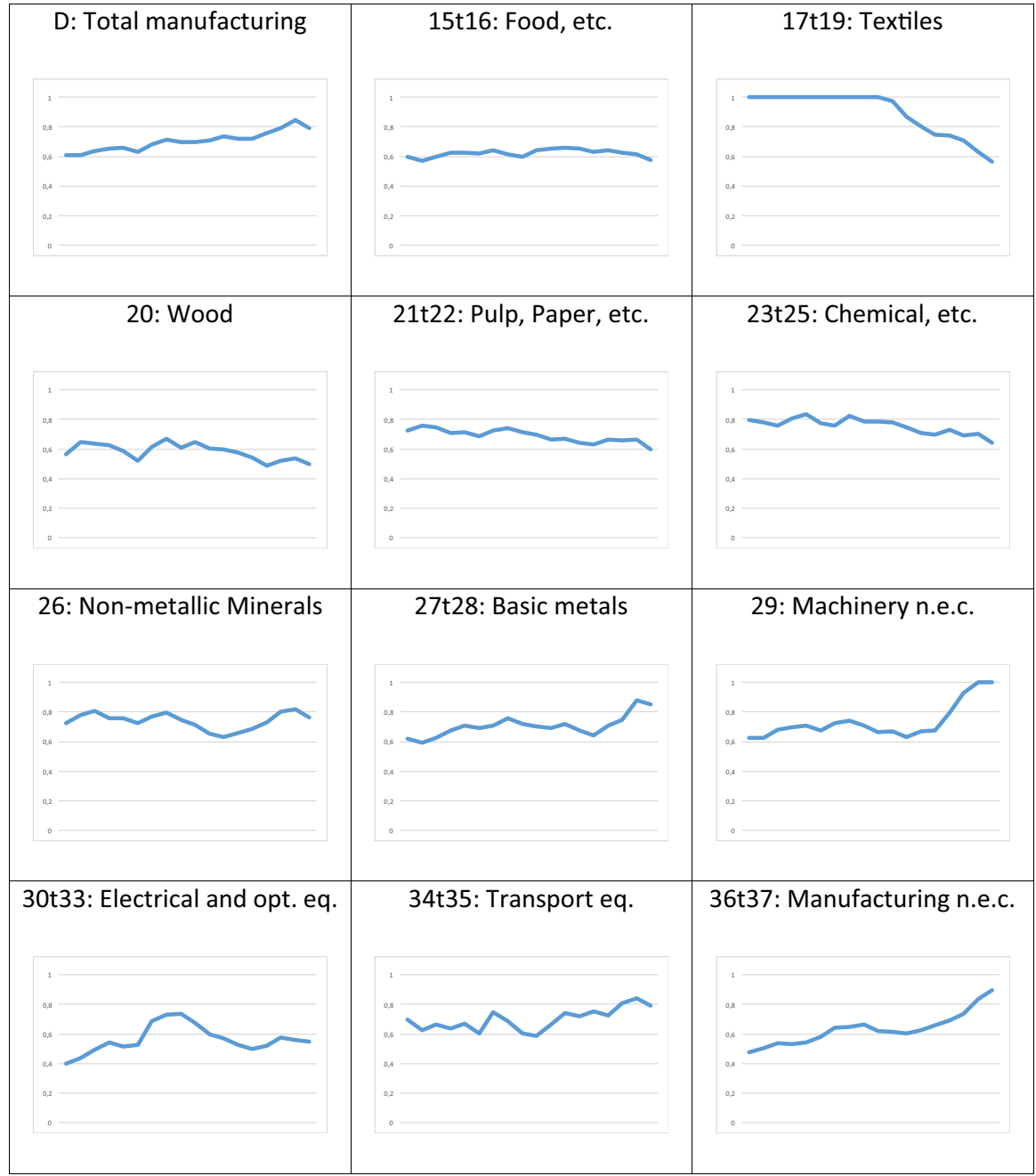

Fig. 9 Japan 


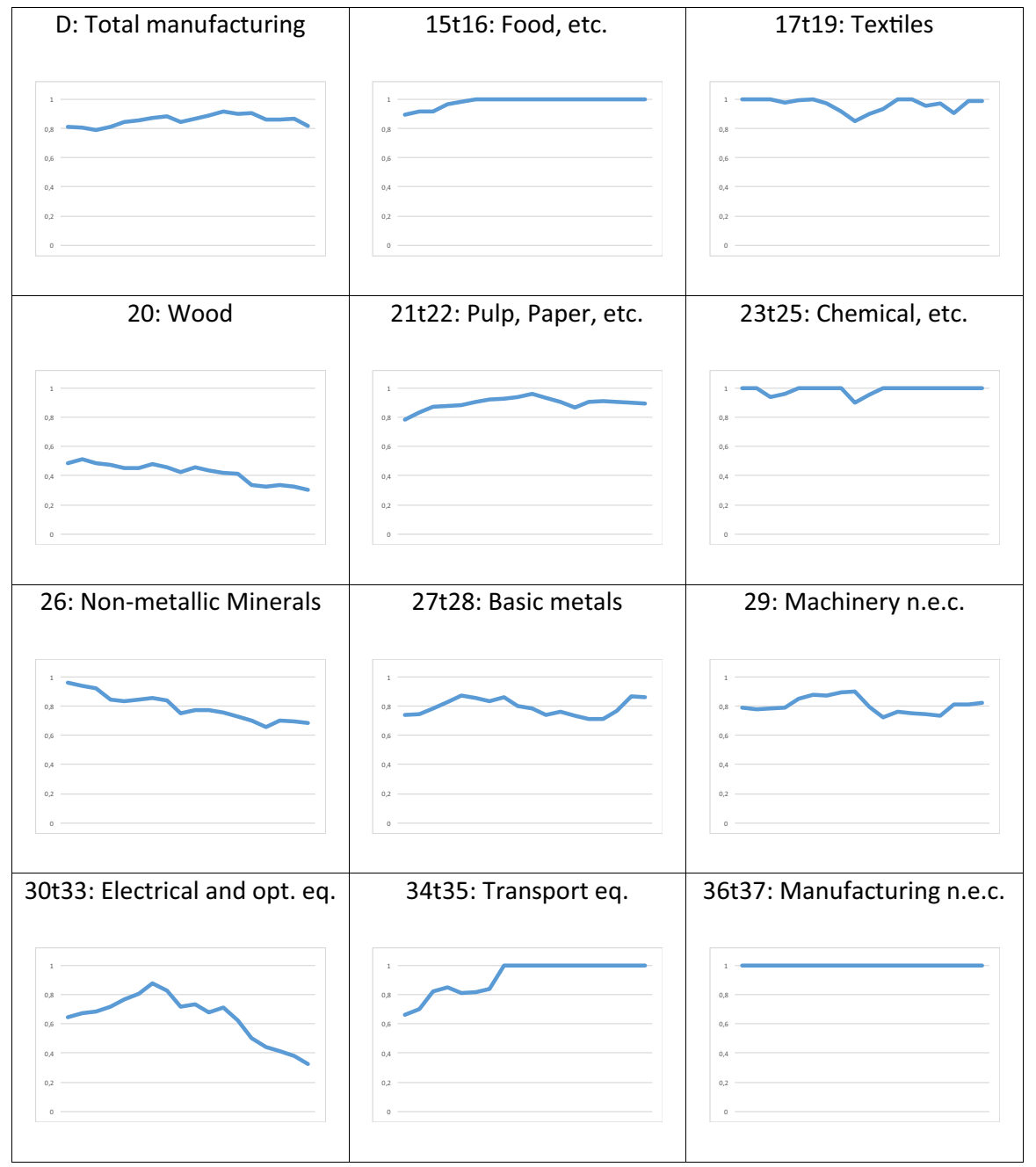

Fig. 10 Netherlands 


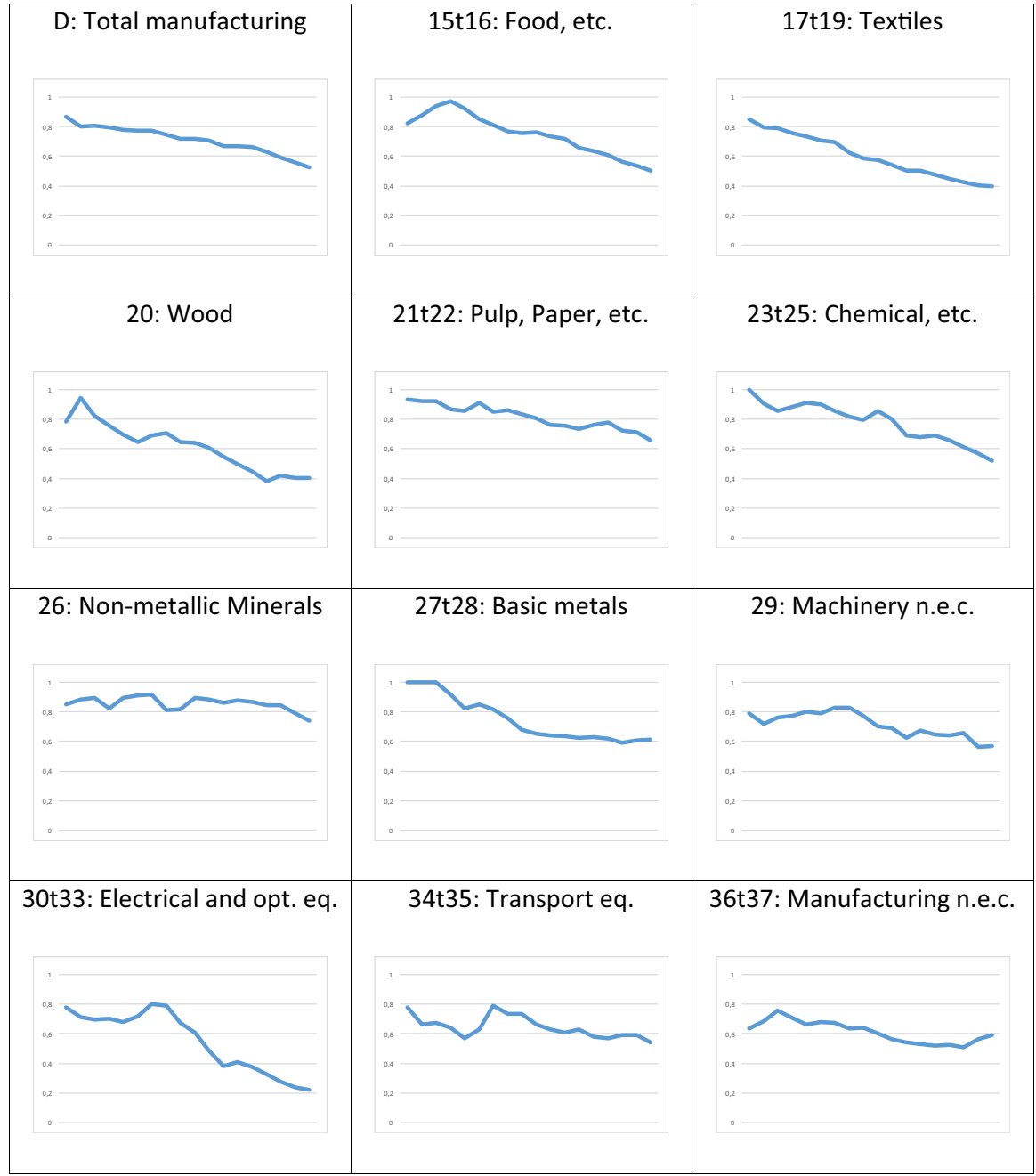

Fig. 11 Spain 


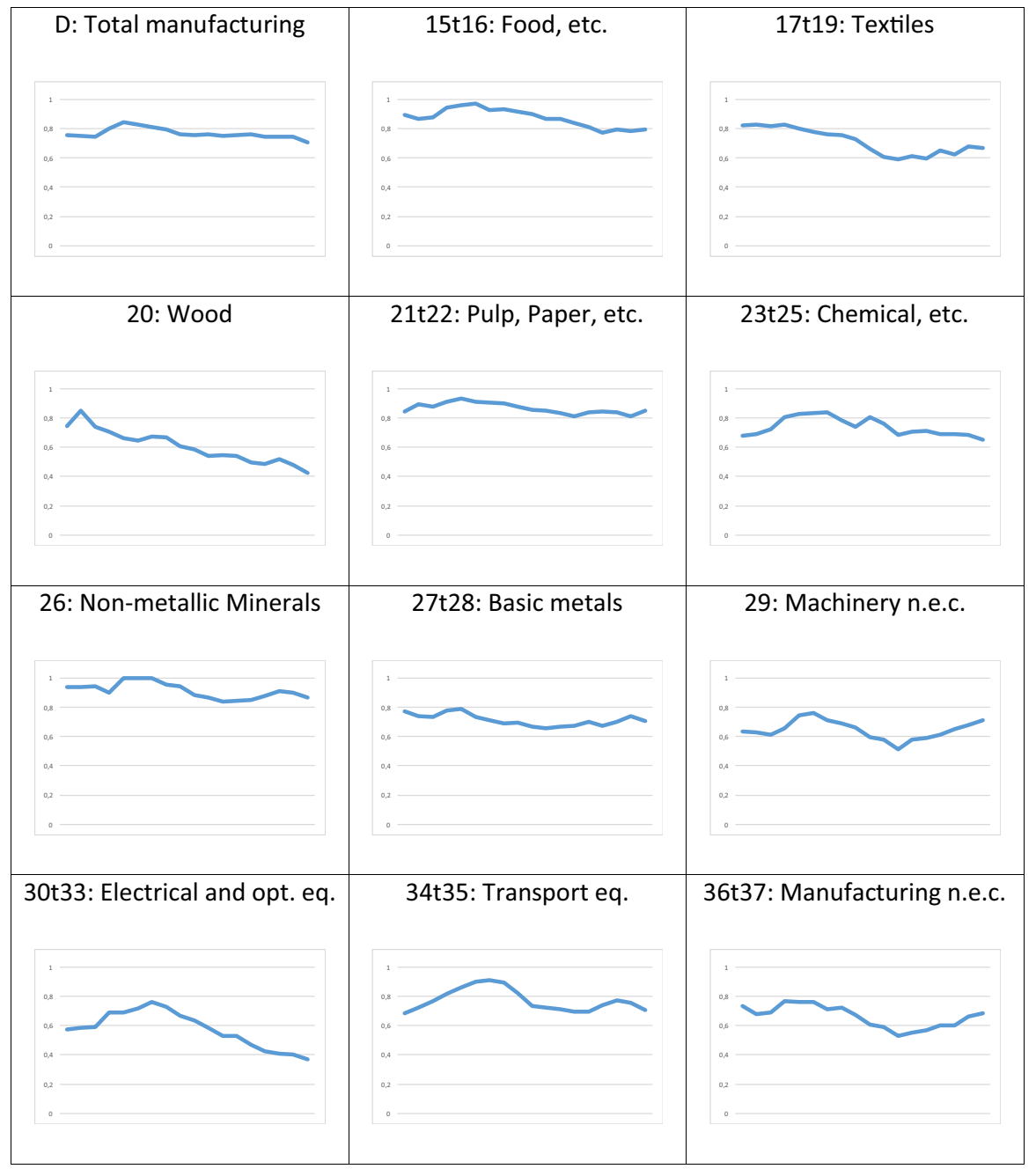

Fig. 12 United Kingdom 


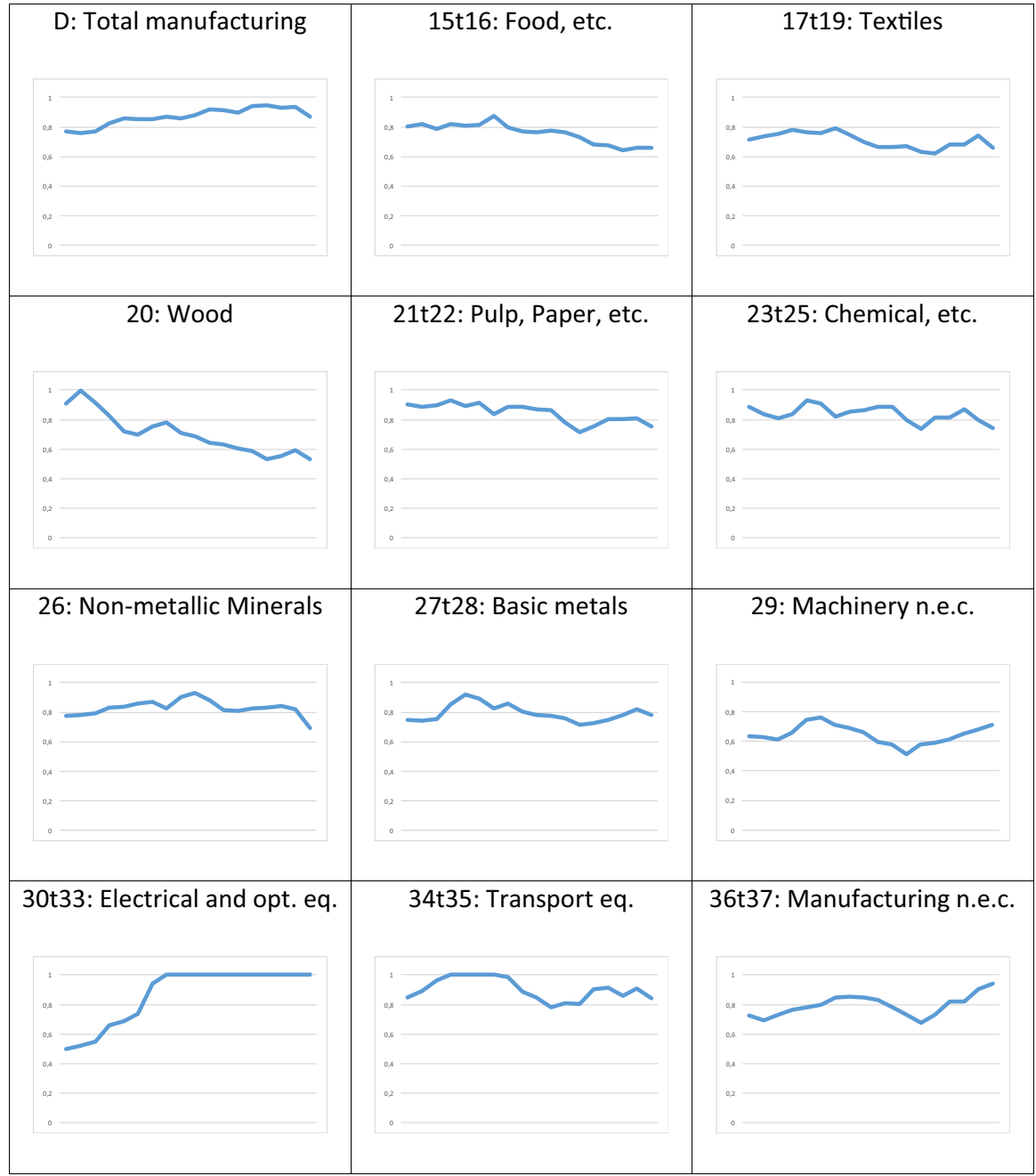

Fig. 13 United States of America 


\section{References}

Acemoglu D, Robinson JA (2012) Why nations fail: the origins of power, prosperity, and poverty. Crown Business, New York

Acemoglu D, Aghion P, Zilibotti F (2006) Distance to frontier, selection, and economic growth. J Eur Econ Assoc 4(1):37-74

Acemoglu D, Autor D, Dorn D, Hanson GH, Price B (2014) Return of the Solow paradox? IT, productivity, and employment in US manufacturing. Am Econ Rev 104(5):394-399. https://doi. org/10.1257/aer.104.5.394

Acemoglu D, Robinson JA, Verdier T (2017) Asymmetric Growth and Institutions in an Interdependent World. J Polit Econ 125(5):1245-1305. https://doi.org/10.1086/693038

Alcalá F, Ciccone A (2004) Trade and productivity. Quart J Econ 119(2):613-646. https://doi. org/10.1162/0033553041382139

Aldieri L, Cincera M (2009) Geographic and technological R\&D spillovers within the triad: micro evidence from US patents. J Technol Transf 34(2):196-211. https://doi.org/10.1007/s1096 1-007-9065-8

Andrews D, Criscuolo C, Gal PN (2016) The best versus the rest: the global productivity slowdown, divergence across firms and the role of public policy (No. 5). OECD Publishing, Paris

Bernard AB, Bradford Jensen J, Redding SJ, Schott PK (2007) Firms in international trade. J Econ Perspect 21(3):105-130. https://doi.org/10.1257/jep.21.3.105

Bloom Nicholas, Van Reenen John (2010) Why Do Management Practices Differ across Firms and Countries? J Econ Perspect 24(1):203-224

Bloom N, Draca M, Van Reenen J (2016) Trade induced technical change? The impact of chinese imports on innovation, IT and productivity. Rev Econ Stud 83:87-117

Bournakis I (2012) Sources of TFP growth in a framework of convergence-evidence from greece. Int Rev Appl Econ 26(1):47-72. https://doi.org/10.1080/02692171.2011.557056

Cameron G, Proudman J, Redding S (2005) Technological convergence, R\&D, trade and productivity growth. Eur Econ Rev 49(3):775-807. https://doi.org/10.1016/S0014-2921(03)00070-9

Cardona M, Kretschmer T, Strobel T (2013) ICT and productivity: conclusions from the empirical literature. Inf Econ Policy 25:109-125

Caves D, Christensen L, Diewert W (1982a) Multilateral comparisons of output, input, and productivity using superlative index numbers. Econ J 92(365):73-86. https://doi.org/10.2307/2232257

Caves D, Christensen L, Diewert W (1982b) The economic theory of index numbers and the measurement of input, output, and productivity. Econometrica 50(6):1393-1414. https://doi.org/10.2307/1913388

Charnes A, Cooper WW, Rhodes E (1978) Measuring the efficiency of decision making units. Eur J Oper Res 2(6):429-444

Clark G (2009) A farewell to alms: a brief economic history of the world. Princeton University Press, Princeton

Clerides SK, Lach S, Tybout JR (1998) Is learning by exporting important? micro-dynamic evidence from Colombia, Mexico, and Morocco. Quart J Econ 113(3):903-947

Coe DT, Helpman E (1995) International R\&D spillovers. Eur Econ Rev 39(5):859-887. https://doi. org/10.1016/0014-2921(94)00100-E

Coe DT, Helpman E, Hoffmaister AW (2009) International R\&D spillovers and institutions. Eur Econ Rev 53(7):723-741. https://doi.org/10.1016/j.euroecorev.2009.02.005

Coelli TJ, Rao DS, O’Donnell CJ (2005) An introduction to efficiency and productivity analysis, 2nd edn. Springer, New York

Cooper WW, Seiford LM, Tone K (2007) Data envelopment analysis: a comprehensive text with models, applications, references and DEA-solver software: Second edition. Data envelopment analysis: A comprehensive text with models, applications, references and DEA-solver software: Second edition pp 1-490. https://doi.org/10.1007/978-0-387-45283-8

Connolly M (2003) The dual nature of trade: measuring its impact on imitation and growth. J Dev Econ 72(1):31-55. https://doi.org/10.1016/S0304-3878(03)00067-1

De Loecker J, Van Biesebroeck J (2016) Effect of international competition on firm productivity and market power (No. w21994). National Bureau of Economic Research, Cambridge

Ding S, Puyang S, Wei J (2016) The Effect of Import Competition on Firm Productivity and Innovation: does the distance to technology frontier matter? Oxford Bull Econ Stat 78:197-227 
Färe R, Grosskopf S, Norris M, Zhang Z (1994) Productivity growth, technical progress, and efficiency change in industrialized countries. Am Econ Rev 84(1):66-83

Gerschenkron A (1962) Economic backwardness in historical perspective: A book of essays, 2nd edn. The Belknap Press of Havard University Press, Cambridge

Giraleas D (2013) The measurement and decomposition of economy-wide productivity growth: assessing the accuracy and selecting between different approaches, PhD thesis, Aston University

Gordon RJ (2016) The rise and fall of american growth: The U.S. standard of living since the civil war. Princeton University Press, Princeton

Griffith R, Redding S, Van Reenen J (2004) Mapping the two faces of R\&D: productivity growth in a panel of OECD industries. Rev Econ Stat 86(4):883-895. https://doi.org/10.1162/0034653043 125194

Grosskopf S (2003) Some remarks on productivity and its decompositions. J Prod Anal 20(3):459474. https://doi.org/10.1023/A:1027364119672

Growiec J (2012) The world technology frontier: what can we learn from the US states? Oxford Bull Econ Stat 74:777-807

Honma S, Hu J-L (2014) Industry-level total-factor energy efficiency in developed countries: a Japancentered analysis. Appl Energy 119:67-78. https://doi.org/10.1016/j.apenergy.2013.12.049

Hufbauer GC, Schott JJ, Kimberley AE, Oegg B (2007) Economic sanctions reconsidered, 3rd edn. Washington, DC, Peterson Institute for International Economics

Iversen T, Soskice D (2019) Democracy and prosperity: reinvention of capitalism in a turbulent century. Princeton University Press, Princeton

Jerome Vandenbussche, Aghion Philippe, Meghir Costas (2006) Growth, distance to frontier and composition of human capital. J Econ Growth 11:97-127

Jorgenson DW, Griliches Z (1967) The explanation of productivity change. Rev Econ Stud 34(3):249283. https://doi.org/10.2307/2296675

Jorgenson DW, Ho MS, Stiroh KJ (2008) A retrospective look at the U.S. productivity growth resurgence. J Econ Perspect 22(1):3-24. https://doi.org/10.1257/jep.22.1.3

Keller W (1998) Are international R\&D spillovers trade-related? Analyzing spillovers among randomly matched trade partners. Eur Econ Rev 42(8):1469-1481. https://doi.org/10.1016/S0014 -2921(97)00092-5

Keller W, Yeaple SR (2009) Multinational enterprises, international trade, and productivity growth: firm level evidence from the United States. Rev Econ Stat 91(4):821-831. https://doi. org/10.1162/rest.91.4.821

Khan T (2006) Productivity growth, technological convergence, R\&D, trade, and labour markets: evidence from the French manufacturing sector. IMF Working Paper No. 230, IMW, Washington

Krugman P (1994a) Peddling prosperity: economic sense and nonsense in the age of diminished expectations, 1st edn. Norton, New York

Krugman P (1994b) The age of diminished expectations: U.S. economic policy in the 1990s, 2nd edn. MIT Press, Cambridge

Kunst RM, Marin D (1989) On exports and productivity: a causal analysis. Rev Econ Stat 71(4):699-703

Kuusi T (2015) The dynamics of ICT adaptation and the productivity gaps across advanced nations. J Prod Anal 44:175-188

Lee KR, Leem BI (2011) Malmquist productivity analysis using DEA frontier in Stata. Working Paper, Stata Conference, Chicago

Lehr W, Lichtenberg FR (1998) Computer use and productivity growth in US federal Government Agencies, 1987-92. J Ind Econ 46:257-279. https://doi.org/10.1111/1467-6451.00071

Lucas RE Jr (1993) Making a Miracle. Econometrica 61:251-272

Madsen JB (2007) Technology spillover through trade and TFP convergence: 135 years of evidence for the OECD countries. J Int Econ 72(2):464-480. https://doi.org/10.1016/j.jinteco.2006.12.001

Mc Morrow K, Röger W, Turrini A (2010) Determinants of TFP growth: a close look at industries driving the EU-US TFP gap. Struct Change Econ Dyn 21(3):165-180. https://doi.org/10.1016/j. strueco.2010.03.001

Melitz MJ, Trefler D (2012) Gains from trade when firms matter. J Econ Perspect 26(2):91-118

Nordhaus WD (2007) Two centuries of productivity growth in computing. J Econ Hist 67(1):128-159. https://doi.org/10.1017/S0022050707000058

North DC (1989) Institutions and economic growth: an historical introduction. World Dev 17:1319-1332 
OECD (2015) The Future of Productivity. OECD Publishing, Paris. https://doi.org/10.1787/97892 64248533-en

Özak Ö (2018) Distance to the pre-industrial technological frontier and economic development. J Econ Growth 23:175-221. https://doi.org/10.1007/s10887-018-9154-6

Pieri F, Vecchi M, Venturini F (2017) Modelling the joint impact of R\&D and ICT on productivity: a frontier analysis approach. DEM Working Paper 2017/13

Romer P (1990) Endogenous technological change. J Polit Econ 98(5):S71-S102. https://doi. org/10.3386/w3210

Schiersch A, Belitz H, Gornig M (2015) Why is TFP growth sectorally concentrated? Appl Econ 47(55):5933-5944. https://doi.org/10.1080/00036846.2015.1061642

Solow RM (1956) A contribution to the theory of economic growth. Quart J Econ 70(1):65-94. https ://doi.org/10.2307/1884513

Souare M (2013) Productivity growth, trade and FDI nexus: evidence from the canadian manufacturing sector. J Technol Transf 38(5):675-698. https://doi.org/10.1007/s10961-012-9259-6

Stiroh KJ (2002) Are ICT spillovers driving the new economy? Rev Income Wealth 48(1):33-57

Van Biesebroeck J (2007) Robustness of productivity estimates. J Ind Econ 55(3):529-569. https://doi. org/10.1111/j.1467-6451.2007.00322.x

Venturini F (2015) The modern drivers of productivity. Res Policy 44(2):357-369. https://doi. org/10.1016/j.respol.2014.10.011

Publisher's Note Springer Nature remains neutral with regard to jurisdictional claims in published maps and institutional affiliations. 